\title{
ACERRA DA CONDUTA INSTINTIVA E DO INSTINTO DOS ANIMAIS
}

\author{
S. DE TOLEDO PIZA JOR. \\ Professor catedrático de Zoologia, Anatomia e Fisiologia da \\ Escola Superior de Agricultura "Luiz de Queiroz" da \\ Universidade de São Paulo
}

\section{INDICE}

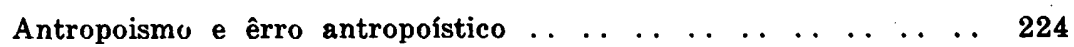

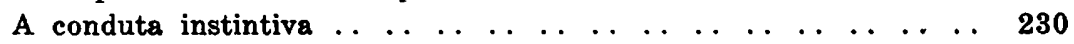

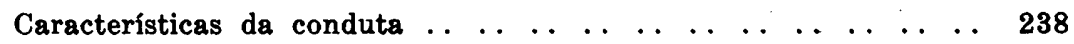

Sôbre a rigidez e a plasticidade da conduta .. . . . . . . . . . 253

Considerações acêrca da conduta instintiva e do instinto .. .. 262

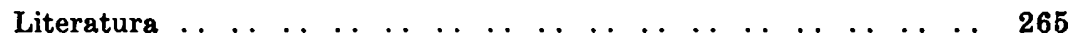




\section{ANTROPOISMO E ERRO ANTROPOISTICO}

Nada há mais difícil para o homem, do que uma apreciação razoável da conduta animal. $\mathrm{E}$ isso, porque, sôbre ser um mau observador, que facilmente se deixa enganar pelas aparências, é em geral um péssimo intérprete dos fenômenos que observa, pois sendo também animal, não consegue libertar-se da tendência que sempre revela de atribuir aos animais impulsos, comportamentos, sentimentos, virtudes ou vícios, as mais das vezes privativos da sua própria natureza. $\mathbf{E}$ assim, o homem chega a pensar que os outros seres vivem e sentem como êle próprio. Que a gata, por exemplo, ao lamber os gatinhos que amamenta, o faz com o mesmo "amor maternal" da mulher que acaricia o filho que lhe suga o seio !... E' a isso que pretendo chamar de antropoismo.

Um belo exemplo dessa maneira antropoística de apreciar a conduta animal, temo-la na comovedora história vivida por um cão de Tóquio, que costumava acompanhar o seu amo à estação, todos os dias, quando êste tomava o trem de subúrbio que o conduzia à Universidade, onde lecionava, e esperá-lo à tarde, por ocasião do regresso. (PIZA, 1935). Havendo, de uma feita, partido para uma longa viagem e falecido, o cão continuou a esperá-lo, como de costume, comparecendo diariamente à estação à hora habitual. A princípio movimentava-se alegremente à entrada do combôio, buscando descobrir o seu amigo dentre os passageiros que desembarcavam. Com o tempo, foi-se acostumando e, como se tivesse compreendido, já não se movia à entrada do trem. Sentado nas patas trazeiras, numa atitude tristonha, apenas movimentava a cabeça para um e para outro lado, na certeza de não ver ninguém. Rumava, taciturno, para casa, e no dia seguinte, à mesma hora, lá estava êle, de novo, na estação.

A ternura que tal procedimento inspirara às pessôas que ali desembarcavam fez com que, por meio de uma subscrição, funcionários da estrada e passageiros erigissem uma estátua ao animal. E essa estátua, lá se encontra, à frente da estação de Shibuya, imortalizando na pedra a figura de um cão, que por anos sucessivos aguardou inutilmente o regresso de um ente querido.

Após nove anos, sem ter dado uma única falta, morreu o pobre animal. Milhares de pessoas, naquele dia, compareceram ao largo da estação para cobrir de flores a estátua e orar pelo eterno descanço da alma do cão.

Essa interessante história mostra de maneira muito clara aquêle antropoismo que faz com que o homem interprete a con- 
duta animal como se fôsse uma conduta humana, descobrindo nela a manifestação dos mais elevados sentimentos que a humanidade desenvolveu no desenrolar de uma longa existência em sociedade, o que o leva a render homenagens a um irracional e cultuar-lhe a memória, do mesmo modo que costuma fazer aos seus semelhantes.

Para mostrar como pode a conduta do animal na natureza arrastar-nos a erros de interpretação, quero citar aqui um exemplo tirado da biologia do Heterospilus coffeicola, a vespinha inimiga da broca do café.

Segundo os estudos de PIZA e PINTO DA FONSECA (1935), realizados em Uganda, Africa Oriental Inglêsa, a fêmea do $\mathrm{He}$ terospilus procura o café atacado pela broca, exatamente no dia em que esta deposita o seu primeiro ôvo na câmara que acabara de construir no interior de um fruto. Aí coloca a vespinha um único ôvo, colado ao da broca, e abandona para sempre aquêle fruto.

Sabendo-se que a broca ainda vai pôr algumas dezenas de ovos no mesmo fruto, pergunta-se por que motivo a vespinha não deixa para mais tarde a sua visita, pois que então poderia encontrar uma câmara, senão repleta, pelo menos com um elevado número dos preciosos ovos de que a sua larva tanto carece para se desenvolver.

A razão parece bem simples. E' que, para o completo desenvolvimento da larva do Heterospilus, são precisos todos os ovos que uma broca costuma pôr. Se a vespinha, por ventura, procurasse o ninho da broca quando a postura desta já se encontrasse avançada, não conseguiria, evidentemente, a sua larva, consumir todo o material que necessita para chegar ao têrmo do seu crescimento. $\mathbf{E}$ isso, porque o tempo decorrido até a eclosão e mais o que a larvinha recém-nascida gasta na consumação de cada ôvo da broca, seriam suficientes para o nascimento das primeiras larvas desta última, e de outras que se seguiriam. Dêsse modo, não só diminuiria o estoque de ovos disponiveis, como se iria aos poucos povoando de larvas a habitação da broca, o que certamente constituiria ameaça muito séria à vida da larva da vespa. Nas condições normais, pois, o Heterospilus põe o seu ôvo sôbre o primeiro ôvo da broca. Esta não toma conhecimento daquele pequenino corpo estranho colado à superfície do ôvo que viera de pôr e prossegue na postura. Quando a larvinha da vespa vem ao mundo, encontra ao lado do ôvo sôbre o qual nasceu, mais alguns ovos. Leva cêrca de dois dias para consumir com aquêle ôvo. Passa para um segundo, que já consegue esvasiar em um tempo um pouco menor. Transfere-se então para um terceiro. $\mathbf{E}$ enquanto 
vai sugando ôvo por ôvo, a broca vai pondo cada vez mais ovos. Chega um momento em que, com a sua capacidade devoradora extraordinariamente aumentada pela idade, a larva da vespa consegue, comendo dois ou mais ovos por dia, dar cabo de todos aquêles que se achavam em depósito. Dêsse momento em diante, crescida e forte, pode suportar muitos dias de jejum. Porisso, se a broca por qualquer razäo suspender temporariamente a postura, não comprometerá com isso a vida da larva da vespa. Esta espera pacientemente por mais alguns ovos, que não tardarão. Quando êstes recomeçarem a vir, ela os irá sugando, de um sorvo.

Eis a razão pela qual, onde quer que se encontre uma larva crescida do Heterospilus, ai nada mais existe que uma fêmea da broca. Fato curioso é que a broca parece não ter tomado conhecimento da presença de um organismo estranho vivendo no seu próprio ninho. Nem ao menos percebe que ali já não existe ôvo algum daqueles muitos que fôra pondo na câmara especialmente construida para tal fim.

O capítulo mais interessante de tôda esta história é sem dúvida o seguinte: Chegando ao término do seu crescimento, a larva da vespa tem que se transformar em adulto. Para isso, metamorfoseia-se. Imobiliza-se no interior de um delicadissimo casulo de seda por ela mesma tecido num dos cantos da câmara em que vivia, e quando, dias mais tarde, dêle sai, já não é uma larva e sim uma perfeita vespinha, macho ou fêmea, de conformidade com a sua constituição genética. Os seus órgãos de infante se consumiram por um processo de histólise, ao mesmo tempo em que a histogênese foi reconstruindo um organismo inteiramente outro. A bôca modificou-se; olhos facetados e ocelos se desenvolveram no alto da cabeça; antenas de muitos segmentos se constituiram na fronte; longas patas articuladas e leves e transparentes asas nasceram-lhe dos segmentos torácicos; espêssa cutícula quitinosa revestiu-lhe todo o corpo; as gônadas se desenvolveram e ela rompe o casulo com a morfologia de um autêntico adulto da sua espécie. Sai para a luz, abandona o fruto do cafeeiro em que nascera e dá início a uma nova e diferente fase do seu ciclo vital.

A metamorfose é uma sorte de novo desenvolvimento embrionário em que órgãos não figurados na anatomia da larva iniciam a sua estruturação e se completam, enquanto outros se formam em substituição aos órgãos larvários que se vãc consumindo. $O$ repouso característico dêsse periodo de ninfose $\dot{e}$, pois, aparente. A larva repousa apenas no sentido de suspender as suas atividades costumeiras : deixa de locomover-se e de nutrir-se. Debaixo da pele ninfal, porém, importantes fenômenos fisiológicos estão se processando com grande inten- 
um tal procedimento tem para a vida da larva que vai nascer; em achar, mais tarde, que a larva da vespa, "ciente" do perigo que correrá ao imobilizar-se para a ninfose na diminuta loja habitada pela broca cujos costumes "aprendeu a conhecer" durante longos dias de estreito convívio, mata-a, "como medida asseguradora" do sucesso da fase mais delicada de todo o seu ciclo vital, que ela "pretende" inaugurar dentro em breve.

Tudo errado. A fêmea do Heterospilus, nada conhece da sua própria história. Nasceu sem saber como nem porque, no interior de um fruto de cafeeiro, de uma ninfa encerrada num casulo tecido por uma larva oriunda de um ôvo posto sôbre um ôvo da broca, por uma fêmea que ela jamais conheceu. Ignora, da maneira mais completa, que tivesse algum dia assassinado uma broca e logo depois construido um abrigo dentro do qual se transformou, de larva que era, no adulto que veio a ser. Sem jamais ter tido qualquer contacto com uma larva da sua espécie, não sabe que ela existe e ainda mais, que tenha que passar por um período de metamorfose e que para isso precise, por sua vez, matar uma broca e construir um casulo.

Nem a vespa, nem a larva, sabe cousa alguma. Quem sabe algo a respeito é apenas o observador credenciado que investiga pacientemente os fatos, concatenando-os numa seriação lógica que exprima de uma maneira mais ou menos exata aquilo que vem a ser a biologia da espécie. Para isso, porém, precisa possuir acurada e profunda educação científica e, em alto grau, a habilidade de montar experiências adequadas.

Vejamos, a título de exemplo, como procede um tal observador, para descobrir o significado biológico do assassínio da broca e mais, que ao praticar um ato de tamanha relevância para a perpetuação da espécie, a larva da vespa procede no mais completo desconhecimento dos benefícios que dêle possam resultar.

Havendo observado que nos frutos em que se encontra uma larva de vespa fiando o seu casulo ou já encasulada, existe sempre uma broca morta, com o corpo esvasiado e o protórax mais ou menos separado, formula a hipótese segundo a qual a broca foi morta pela larva da vespa. Esta hipótese pode ser facilmente verificada pela observação direta. Examinando um grande número de frutos atacados, terá inúmeras oportunidades de assistir à luta que se termina pela morte e esvasiamento da broca. Logo após assistirá ao início da confecção do casulo por parte da larva vencedora. 
Qual será então o motivo que leva a larva da vespa a proceder daquela maneira ? Eis uma questão difícil, para cuja solução não mais se pode recorrer à observação direta. A primeira hipótese que ocorre ao investigador é que para as transformações que se vão operar no organismo da larva durante um período de cêrca de 15 dias, necessita ela de um refôrço alimentar que venha aumentar as suas reservas e por essa razão devora a broca e sem perda de tempo começa a tecer o casulo.

Essa hipótese pode ser verificada da seguinte maneira :

Em frutos de cafeeiro preparados de sorte a permitir a observação sob a lupa do que se passa na câmara habitada por uma broca e uma larva a têrmo do Heterospilus, introduzem-se inúmeros ovos colhidos de outros frutos, oferecendo-se dessa maneira abundante material nutritivo à larva prestes a entrar em luta. Verifica-se então, que, chegado o momento, a larva mata a broca como de costume e tece o seu casulo sem tocar nos ovos que lhe foram postos à disposição. Pode-se querer dai concluir, não ter sido a necessidade de um suplemento nuiritivo o móvel do assassinio. Pois do contrário, pareceia mais natural que a larva preferisse o seu alimento habitual e sugando uma dezena de ovos ou mais, entrasse em ninfose sem atacar a broca. Uma tal ccnclusão, porém, seria ilegítima, visto como, pode muito bem acontecer, que nos últimos momentos de vida livre, como preparativo para a metamorfose, precise a larva, não mais de ovos e sim de um alimento diferente, qual o fornecido pelos tecidos da broca adulta. E' verdade, que contra esta suposição está o fato da larva não se utilizar da broca como alimento, mesmo quando submetida a prolongado jejum. Em todo caso, a experiência poderá decidir a questão.

Coloque-se à disposição da larva uma boa porção de ovos da broca e retire-se esta última da câmara no momento em que a primeira dá início à luta, procurando nela enroscar-se. $O$ resultado é, que sem haver sugado a broca e nem os ovos, a larva tece o casulo e se transforma normalmente em inseto adulto. Agora pode-se concluir que não é para nutrir-se que a larva do Heterospilus assassina a broca do café.

De outro lado, retirando-se a broca das câmaras em que o Heterospilus se acha encasulado e nelas colocando-se uma broca viva, constata-se que em muitos casos a ninfose não consegue completar-se. Por conseguinte, o extermínio da broca redunda de fato numa garantia de vida para a larva enclausurada num tênue casulo de seda.

Resta-nos agora investigar se a larva revela qualquer conhecimento acêrca da finalidade do ato que pratica. Para isso, ao aproximar-se o momento da luta, substituamos a broca viva 
por uma broca morta. Dentro em pouco, a larva da vespa, sem demonstrar o menor conhecimento da nova situação, assume a atitude costumeira, enrodilha-se ao corpo do indefeso animal e "mata-o" uma segunda vez. Em seguida, tece o casulo e entra em ninfose.

Se, de outro lado, au iniciar a luta, introduzirmos na câmara uma broca suplementar, esta será poupada. Morta a primeira broca, a larva da vespa procede como se a segunda năo existisse. Esse modo extravagante de proceder em face de uma broca morta ou de uma suplementar revela que a larva do Heterospilus não tem noçäo alguma acêrca do significado da sua própria conduta. Um impulso de matar acomete-a ao completar o seu desenvolvimento e êsse impulso ela descarrega na sua vítima, mesmo que já esteja morta. E' um impulso inato que se satisfaz com uma única descarga e uma vez satisfeito compele-a à construçäo do casulo, mesmo que uma segunda broca permaneça viva ao seu lado.

\section{A CONDUTA INSTINTIVA}

O Heterospilus é um Microhimenóptero Braconideo de hábitos solitários. $\mathrm{O}$ cuidado da fêmea para com a prole consiste tão, sòmente em descobrir uma câmara nova da broca e nela depositar um único ôvo. Do destino dêsse ôvo ela näo toma conhecimento. the se desenvolve como os demais ovos da espécie e a larva a que dá origem se comporta como as suas irmäs nascidas em outros frutos do cafeeiro.

Himenópteros há, entretanto, que trabalham um pouco mais para assegurar o desenvolvimento de seus descendentes. Têm que sair à caça do animal que constitui o alimento exclusivo de suas larvas, paralisam-no com o produto de suas glândulas veneniferas, arrastam-no, às vezes com grande dificuldade, para uma toca, um buraco ou um ninho de barro adrede construidos, introduzem-no aí, pöem um ou mais ovos no corpo de sua vítima ou nas paredes do abrigo, fecham êste último da melhor maneira possivel para impedir a entrada de formigas e de outros predadores, e desaparecem para sempre.

Ao nascer, dentro de alguns dias, as larvas encontram ainda adormecidos ou já voltados à atividade, os insetos adultos, as lagartas ou as aranhas que para ali foram trazidos, e se pöem imediatamente a devorá-los.

A carga dos ninhos é calculada de conformidade com as exigências da prole e é sempre suficiente para o completo desenvolvimento das larvas que väo nascer. 
Depois de muitos dias de vida encarcerada, quando o alimento disponível está prestes a esgotar-se, as jovens prisioneiras entram em ninfose, metamorfoseiam-se e rompem para a luz.

Ao chegar o momento da postura, após alguns dias de vida livre, as fêmeas, que nasceram na escuridão de um ninho hermeticamente fechado, procuram caçar aquêles mesmos animais que os seus antepassados vinham utilizando desde tempos imemoriais com êles lutam da mesma maneira e repetem tôdas aquelas cenas de entorpecer, arrastar e enclausurar as suas vítimas, como se tudo aquilo lhes fôsse transmitido por uma tradição secular. E no entanto, jamais aprenderam cousa alguma dos seus ancestrais.

Para bem apreciar a conduta dêsses Himenópteros, vejamos alguns exemplos colhidos à biologia das chamadas Vespas Solitárias.

Muita gente deve ter visto belas vespas de côr azul metálica ou de corpo vivamente ornado de amarelo, tentando subjugar uma aranha ou um inseto, às vezes bem mais volumosos que elas próprias, ou arrastando-os, já paralisados, para algum lugar.

Suponhamos uma caçadora de aranhas.

Chegado o momento da postura ela sai à caça e logo descobre a aranha que the convém. Lança-se sôbre ela e uma luta muito movimentada se trava com o Aracnídeo que procura a todo o transe repelir a agressão.

Observadores muito credenciados e dentre êles o célebre naturalista francês, FABRE, afirmam que a vespa procede como se ela conhecesse a anatomia do animal com que luta, procurando atingir com o seu aguilhão, primeiro os gânglios nervosos que comandam os movimentos das poderosas e veneníferas quelíceras e depois aquêles que governam a movimentação das patas. Uma vez paralisada a armadura bucal, o que a vespa só consegue após avanços e recuos geralmente frenéticos, já se torna bem mais fácil a inoculação da peçonha entorpecente no gânglio torácico, o que acarretará a completa imobilidade de sua antagonista.

A favor da tese segundo a qual a vespa conhece a organização interna do seu contendor, afirmam certos autores, que, se os gânglios locomotores forem concentrados numa única massa nervosa localizada no tórax, como acontece com muitos insetos adultos, a vespa não dá mais do que uma ferretoada, procurando atingí-la pela parte ventral do corpo, onde ela se acha situada. Pelo contrário, se os gânglios nervosos se encontrarem distribuidos pelos diversos segmentos, como se verifica com as lagartas, a vespa repetirá as suas picadas ao longo de 
todo o corpo, até conseguir completa paralisação de todos os movimentos.

Quanto à duração da ação entorpecente, as observaçōes discordam. Para alguns, a paralisia dura até o nascimento das larvas. Quer dizer, quando estas vêm ao mundo, a vítima se acha ainda imobilizada, porém viva. Para outros, o efeito é pouco duradouro, apenas facilitando o transporte da vítima para o buraco ou para o ninho, onde os movimentos vão-se gradativamente reaparecendo. Porém, quando isso acontece, a vítima já se encontra enclausurada e o ôvo em lugar seguro, de sorte que nem o desenvolvimento embrionário será prejudicado, nem o animal poderá escapulir-se à sanha devoradora das larvas que vão nascer.

O certo é, que o veneno inoculado não é mortífero. Dure o tempo que durar o desenvolvimento dos ovos da vespa, as larvas que dêles nascerem precisam de tecidos vivos para nutrirse. Uma carangueijeira do gênero Pamphobeteus recolhida para - laboratório quando estava sendo conduzida por uma Pompilidae não identificada que acabara de picá-la, permaneceu imóvel por 45 dias, findos os quais foi sacrificada para estudo. Os seus tecidos apresentavam o mesmo aspecto dos tecidos normais. Conhecem-se, entretanto, casos, em que a vítima imobilizada, dentro de pouco tempo começa a mecher-se, para daí a alguns minutos recuperar todos os seus movimentos. E' porisso que certas vespas que capturam baratas ou grilos têm o cuidado de pôr o seu ôvo numa região bem escolhida do corpo da vítima, que esta, ao voltar a si do efeito paralisante do veneno, não poderá alcançá-lo nem com as peças bucais, nem com as patas e nem mesmo atritá-lo contra as paredes do ninho. Algumas há, que amputam as pernas de suas vítimas, enquanto adormecidas, num excesso de zêlo pela subsistência da prole. Aliás, essa sabedoria inata chega a ser requintada em certos animais. Recorde-se, por exemplo, o caso do Galeodes (Solpúgida) das proximidades de Bagdá, referido por HINGSTON (1929), o qual, sempre que entra em luta com um grande escorpião negro do deserto, sabe desarmá-lo, amputando-lhe o último segmento da cauda, que se termina pelo dardo venenífero, ou esmagando-o com suas poderosas quelíceras.

Depois dessa pequena digressão, retomemos o fio de nossa narrativa.

A vespa caçadora de aranhas, uma vez paralisada a sua vítima, arrasta-a para o buraco. Arrasta-a, é bem o têrmo, porque empurrá-la seria ilógico e suspendê-la no vôo, impossível em vista do pêso da carga. Arrasta-a, como nós arrastamos um fardo que nẩo conseguimos erguer. Recolhe-a em seguida, de- 
sova nela, tapa muito bem o orifício de entrada, esparrama sôbre êle terra, areia, pedrinhas, fôlhas, tudo, enfim, que ali se encontrava antes, para disfarçá-lo da melhor maneira, e dá por terminada a sua missão.

Os filhotes que vêm ao mundo metamorfoseiam-se e ao cabo de algum tempo, do buraco saem os adultos.

Quando chegar a hora da reprodução, as fêmeas repetirão a mesma série de atos, tomando sempre as mesmas atitudes. Constroem um buraco em tudo semelhante ao que fôra construido pela sua genitora, saem à caça de uma aranha e sem dificuldade descobrem um exemplar daquela mesma espécie, que, quando larvas, encontraram ao nascer; lutam com ela da mesma maneira, executando aquêles mesmos frenéticos avanços e recuos até que conseguem picá-la e imobilizá-la; arrastam-na para o ninho, desovam nela, fecham e entrada e espalham sôbre ela o material que se encontra nas imediações. Tudo como sempre.

Passam-se os meses, passam-se os anos, passam-se os séculos, e a caçadora de aranhas repete sempre os mesmos atos. Nada se modifica. E assim ela procede, no Amazonas ou em S. Paulo, onde quer que exista. As cenas que irá representar amanhã, serão aquelas mesmas cenas representadas por todos os seus antepassados: uma reedição ipsis virgulis, sem nenhuma alteração quer na ordem dos atos, quer no desempenho dos papéis.

Como tudo isso nos empolga, ao mesmo tempo que desafia a nossa argúcia!

Cada espécie de vespa solitária vive a sua vida a seu modo. Umas caçam lagartas, outras grilos, outras baratas. Umas fazem um buraco no chão, outras constroem um potinho de barro num muro, na parede de uma casa, num galho de árvore, porém sempre da mesma forma. Há as que preferem não abrir buracos e muito menos construir potinhos: desentocam a sua vítima, perseguem-na, atacam-na, paralisam-na e a arrastam para o seu próprio ninho, no qual a introduzem para em seguida obstruirem a entrada. Há até aquelas, que depois de entupirem com terra a bôca do buraco, munem-se de uma pedrinha, para com ela socá-la. Algumas reduziram ao mínimo a sua atividade. Não lutam, não paralisam, não constroem ninho. Limitam-se a colar o seu ôvo no corpo da vítima, sem molestá-la. O resto virá por si.

Em face de tanta coisa maravilhosa, vem-nos o desejo irresistível de indagar do motivo de tudo isso. Porque será que algumas vespas não introduzem nos seus métodos algo que nos parece mais perfeito do método de outras? 
A resposta talvez fôsse, porque as vespas nada têm que ver com o conceito que nós, observadores da sua conduta que nos encontramos à margem dos seus problemas, fazemos acêrca da perfeição.

Nós só poderemos julgar da maior ou menor perfeição do trabalho de uma vespa, apreciando-o sob um prisma humano. $\mathrm{E}$ aí, mais uma vez, aparece o êrro antropoístico. A vespa não entende as coisas como nós. Aquilo que achamos poderia constituir um melhoramento no trabalha rotineiro de uma vespa é exatamente aquilo que pensamos poder fazer se acaso fôssemos vespa.

Que êrro gigantesco! Se por ventura fôssemos vespa, haveríamos, por certo, de viver, sentir e agir como vespa. Para a vespa, nada existe mais perfeito do que aquilo que ela executa. Tudo que faz está de conformidade com as leis naturais que regem os fenômenos do Universo e não poderia ser feito senão daquela maneira. Não existindo outra alternativa, a conduta da vespa é perfeita. E' perfeita, exatamente, por ser única, e, consequentemente, por não poder ser ultrapassada.

De acôrdo com essa ordem de idéias, tudo o que existe ou acontece no mundo, é perfeito. $E^{\prime}$ perfeito porque existe ou acontece em obediência ao imperativo de leis imutáveis. $\mathbf{E}$ a perfeição reside nas próprias coisas ou nos acontecimentos. E', portanto, absoluta.

Imaginemos um fruto que se desprende do galho e tomba. Ao cair, deixa de seguir a vertical e é projetado à distância por uma rajada. Queda imperfeita ? Não, absolutamente não. Como fenômeno único, perfeito. Nas condiçōes em que se realizou a queda, esta não poderia ter sido de outra maneira.

A perfeição relativa é cousa diferente. Depende da comparação de objetos ou de comportamentos e da escolha de um padrão. Mais ou menos perfeito seria aquilo que mais ou menos se aproximasse do padrão aferidor.

A perfeição relativa só existe desde que haja quem possa fazer avaliações e confrontos. E êsse "quem", é o homem. Se retirarmos o homem do cenário do mundo, com êle desapa. recerá a perfeição relativa das coisas. Só restará então a perfeição absoluta, inerente a todos os fenômenos. Aliás, o homem é uma das criaturas mais novas do planeta. Quando êle apareceu, a vida era já velha sôbre a terra. Seres de tôdas as classes zoológicas, do Protozoário ao Mamífero, viveram uma longa existência num mundo destituido de homem. $\mathbf{E}$ tudo então era perfeito. Perfeito de modo absoluto. Não havia quem comparasse as cousas e por conseguinte a perfeição relativa 
não existia. Tôdas as criaturas eram perfeitas em grau absoluto. A ameba, como ameba, não poderia ser mais nem menos perfeita que a ameba. E nem a ave, estruturada como ave, poderia ser mais perfeita que o réptil, estruturado como tal e como tal vivendo e sentindo.

Sendo a perfeição inerente à natureza do ser, a conduta de uma espécie de vespa é tão perfeita quanto a conduta de outra e porisso cada qual vai desenrolando o fio de sua existência sem necessidade de introduzir nela qualquer sorte de modificação ou de adotar novos métodos.

Convenhamos que os conceitos aqui emitidos acêrca da perfeição, em nada nos auxiliam a compreender a conduta animal. Prossigamos, porisso, até a completa satisfação da nossa curiosidade.

Se tôdas as condutas são perfeitas, qual será a razão da existência de tantas e tão diferentes condutas? Gostaríamos de saber por que motivo umas vespas caçam aranhas, enquanto outras só capturam lagartas, grilos ou baratas; umas cavam um buraco na terra, ao passo que outras constroem ninhos de barro ou se servem da própria toca em que suas vítimas se escondem.

A razão de tudo isso está no fato de espécies diferentes terem condutas diferentes. A conduta difere de uma espécie pa. ra outra, assim como as espécies diferem entre si. Isso significa que a conduta é um atributo específico e portanto, que as espécies se caracterizam também pela conduta. A conduta pertence ao patrimônio da espécie, como qualquer outro caráter. A razão pela qual uma dada espécie exibe uma certa conduta é a mesma pela qual ela exibe as suas demais características. Número de artículos das antenas, forma, dimensões e coloração das diversas partes do corpo, presença ou ausência de ocelos, aspecto transparente ou opaco das asas, têm a mesma significação da conduta para a diferenciação específica das vespas.

Poderíamos então afirmar, que uma espécie tem esta conduta e outra aquela, pelos mesmos motivos pelos quais uma possui olhos azuis e outra vermelhos. Evidentemente, nada faríamos, com tal afirmativa, senão deslocar o problema: Para compreender a diferença de condutas, tornar-se-ia necessário compreender primeiro a diferença de coloração dos olhos.

Ora, a coloração dos olhos, como aliás qualquer outro caráter do organismo, varia de espécie para espécie, porque estas estão permanentemente sujeitas às leis biológicas que regem o seu desenvolvimento, a sua vida e a sua evolução. 
De conformidade com as leis da hereditariedade, cada espécie animal, ao procriar-se, transmite aos descendentes os atributos da comunidade. E' porisso que as espécies se conservam através dos tempos, permitindo-nos reconhecê-las em qualquer ocasião. Se compararmos um exemplar da belíssima e gigantesca Pepsis hoje capturado, com o espécime que PERTY (1830), há mais de cem anos, figurou no seu Delectus Animalium, constataremos a imutabilidade dos carateres especificos. Essa imutabilidade, entretanto, não exclui a possibilidade das chamadas variaçōes individuais. Circunstâncias particulares podem determinar pequenas divergências de côr, de forma ou de dimensöes. Embora todos os caracteres da espécie estejam presentes em cada indivíduo, indivíduos perfeitamente iguais não existem. Porém, as divergências não afetam a natureza íntima do caráter. Pelo fato dos olhos vermelhos de um indivíduo serem um pouco mais desbotados ou mais carregados do que os de um outro, ou das tíbias do primeiro possuirem alguns espinhos a mais do que as do segundo, nem porisso deixaremos de reconhecer que ambos apresentam a coloração dos olhos e a armação das tíbias típicas da espécie a que pertencem.

Ao lado dessas variações inteiramente destituidas de significação, outras existem, que pela sua natureza são capazes de alterar de modo muito significativo a situação. Para estas reserva a Biologia o nome de mutaçōes.

A mutação é uma variação brusca, inesperada, imprevisível, que modifica de maneira permanente o caráter do individuo. Assim, numa população de cobáios de pêlos lisos pode nascer um indivíduo de pêlos crespos, sem que ninguém seja capaz de prever um tal acontecimento. Assim também, dt vespas de olhos vermelhos, pode surgir uma vespa de olhos a. zuis. $O$ caráter primitivo foi, nos indivíduos que mutaram, radicalmente substituido pelo novo caráter. $E$ dêsse modo, ao se reproduzir, o cobáio de pêlos crespos, bem como a vespa de olhos azuis, vão disseminando essa novidade no seio da população.

A mutação mostra-se hereditária desde o seu aparecimento. Se os individuos por ela modificados também se modificarem do ponto de vista fisiológico, não mais conseguindo se reproduzir com os outros membros da espécie, mas apenas entre si, os mutantes se converterão numa espécie distinta daquela que lhes deu origem.

E' êsse o mecanismo responsável pela multiplicidude das espécies. A seleção natural decide-lhes da sorte. Se elas, ao nas- 
cer, encontrarem condições favoráveis de vida, fixam-se. Do contrário, mais cedo ou mais tarde deixarão de existir.

Estamos agora de posse dos conhecimentos que nos permitirão compreender os motivos pelos quais umas vespas têm olhos vermelhos e outras têm-nos azuis. $\mathbf{E}$ como o tipo de conduta que vimos analisando tem a mesma significação biológica que a côr dos olhos ou quaisquer outros caracteres somáticos pelos quais as espécies se distinguem, sendo, como aquêles, hereditária e portanto inata, e como aquêles sujeita a mutações, compreenderemos também a razão pela qual umas vespas só caçam determinadas espécies de aranhas e fazem buracos na terra, ao passo que outras procuram grilos ou baratas, arrastando-os para a sua própria toca ou introduzindo-os em potes de barro, tão característicos, que sòmente pela sua forma poderemos saber a que espécie pertencem.

Talvez o leitor jamais tenha visto um dêsses potinhos em que certas vespas solitárias enclausuram as suas vítimas em estado dormente, para repasto das larvas que irão em breve nascer. Mas, ninho de João de Barro, todo mundo conhece. E sabem todos, que onde quer que exista João de Barro, aí êle sempre constroi o mesmo tipo de ninho, de sorte que, só pelo exame do ninho, se poderá fazer uma idéia exata da ave que o construiu. Para definir o João de Barro como espécie, as características do ninho valem tanto, quanto a forma, as dimensões e a coloração das diversas partes do corpo.

Uma vespa não altera a sua conduta, pelo mesmo motivo pelo qual ela não pode alterar a côr dos olhos ou o número de artículos das antenas. Porém, assim como a mutação pode modificar uma estrutura e fixá-la como um atributo novo e permanente do grupo, pode igualmente modificar de modo definitivo a conduta, estabelecendo, assim, um tipo novo, diferente do primitivo.

Poderemos, pois, concluir, que, de um modo geral, existem tantas condutas, quantas espécies.

Vimos, de outro lado, que uma outra sorte de variação se opera no seio da comunidade específica, que, pela sua natureza, não consegue alterar o patrimônio genético da população. $\mathbf{E}^{\prime}$ porisso que os caracteres individuais variam na sua expressividade, sem contudo conseguirem alcançar um novo significado biológico. Os olhos vermelhos podem ser mais ou menos claros ou escuros, maiores ou menores, um pouco mais redondos ou oblongos, sem deixarem de ser os olhos vermelhos típicos da espécie. Isso denota uma certa plasticidade da expressão do caráter, que se verifica também com a conduta. Sem que esta venha a perder as suas características específicas, pode apresen- 
târ variaçõès dèstituidas de qualquer importância para a história do grupo, as quais, não ultrapassando jamais as fronteiras que as delimitam, introduzem um cunho de individualidade na maneira de proceder de cada membro da espécie. Assim pois, podemos afirmar igualmente aqui, que embora se trate da mesmissima conduta, reconhecida como patrimônio da espécie, näo.se consegue encontrar dois procedimentos que se sobreponham de modo absoluto.

\section{CARACTERISTICAS DA CONDUTA}

A conduta que estamos estudando tem características sumamente importantes; que merecem ser salientadas. Assim, ela se-inicia da mesma maneira em todos os membros da espécie quando êstes atingem uma certa fase do seu ciclo vital, como se um móvel oculto os compelisse, de modo inevitável, à prática do ato que a inaugura. Daí por diante, ela prossegue, com as mesmas características, até $o$ ato final, passando por uma série de. atos intermediários; que são sempre os mesmos e se desenrolam sempre na mesma; sequência.

O grau de complexidade da conduta, varia de espécie para espécie. A fêmea do Heterospilus, como vimos, no momento da desova, limita-se a procurar num fruto de cafeeiro uma broca em início de postura e aí colocar um único ôvo. Já a caçadora de aranhas, na mesma situação, trabalha muito mais. Prepara, antes-de tudo, um ninho. Sai depois à caça de uma aranha. Descoberta esta, com ela trava renhido combate. Vencedora, arrasta para o ninho o corpo inerte da vítima: Aí chegando, recolheo, nêle desova, vem para fora e fecha a entrada do ninho.

Pelo que até agora conhecemos acêrca da conduta, poderemos considerá-la,- resumidamente, como sendo inata, sujeita às leis da variaçăo individual e da hereditariedade $e$, consequentemente, como sendo patrimônio da comunidade.

Logo teremos ocasiāo de analisar outros aspectos da conduta: Antes de o fazermos, porém, busquemos compreender 0 seu mecanismo, ou mais propriamente, as suas determinantes biológicas.

Não deỉxa de causar-nos estranheza o fato da vespa caçadora descobrir, no momento oportuno, a lagarta que lhe convém, sendo que dezenas e dezenas de outras lagartas existem na região: Mas, se soubermos que a vespa guia-se pelo. olfato e que - cheiro específico e portanto único da lagarta que lhe serve, a atrai, e como um fio invisivel, arrasta-a para ela, o ato da descoberta da prêsa adequada se revieste de extrema simplicicidade. O.que se exige da vespa para se compreender a segurança com 
que vai ela ao encontro de uma determinada espécie de 'lagarta, é tão sòmente uma elevada acuidade olfativa para um cheiro particular, que é exatamente aquêle que se desprende da lagarta ém questão. Agora, o que nos traz embaraços é admitir que o sentido do olfato possa alcançar um tal grau de desenvolvimento. Poderá mesmo uma vespa, a dezenas e até centenas de metros, sentir um cheiro que nós não conseguimos perceber nem quando nos encontramos a um palmo de distância ? Pode.

A faculdade de sentir o cheiro das coisas atinge em alguns animais e particularmente nos Insetos, níveis inconcebíveis.

Conhecem bem os caçadores o faro dos cães. Pois' êsses animais, segundo BUYTENDIJK (1936), sentem o ácido sulfúrico na diluição de 1:10.000.000. Têm realmente o olfato tão apurado, que conseguem descobrir um determinado cheiro mascarado por muitos outros cheiros diferentes. A prova disso se encontra na velha e interessante experiência de ROMANES (1887), réferida com frequência na literatura sôbre o assunto. Aquêle conhecido investigador do instinto e da inteligência dos animais, para evidenciar o poder discriminativo do olfato dos cães, percorreu uma distância de cêrca de 200 metros, seguido por mais onze pessoas que iam colocando cuidadosamente os pés sôbre as pegadas por êle deixadas. Ao cabo dêsse percurso, ROMANES, acompanhado por cinco homens, quebrou para a direita, ao passo que a outra metade do bando rumou para a esquerda. Depois de uma longa caminhada em sentidos opostos, os doze indivíduos se ocultaram e um animal foi colocado no início da pista, com a determinação de descobrir o seu amo. Embora onze pessoas distíntas houvessem calcado com os -pés os rastos de ROMANES, a cadela submetida ao teste não teve dificuldade em encontrá-lo, rumando decididamente para a direita, no ponto em que a pista se dividia.

Igualmente interessante é a experiência feita pór BUYTENDIJK com um cão policial.

Cada uma das seis pessoas reunidas atira uma pedra a uma certa distância. A Alberto, o cão, fizeram cheirar a mão de um dos circunstantes e ordenaram-lhe fôsse buscar a pedra respectiva, o que foi realizado.

Que abismo separa o nosso mesquinho olfato, do olfato apuradíssimo dos cães!

Os Insetos, que têm servido para um sem número de pesquisas, são também dotados de órgãos olfativos de extraordinário poder. Quase tudo, na sua vida de relação, depende do olfato. Sem o olfato, abelhas, formigas e cupins jamais se teriam organizado nessa vida social que tanto nos encanta. Das experi- 
ências de FABRE e de LUBBOCK se deduz ser o olfato o guia seguro que permite às formigas seguir a pista traçada por uma companheira, do ninho a uma fonte nutridora recém-descoberta. E' pelo olfato que êsses pequeninos seres reconhecem os membros de sua comunidade e - cousa extraordinária - distinguem, na subterrânea obscuridade de sua habitação, cada uma das suas companheiras.

Vejamos, a título de exemplo, uma simples e concludente experiência de LUBBOCK (1883), que bem atesta a importância do olfato na vida das formigas.

Aquêle distinto investigador ligou um de seus ninhos de formigas a duas placas de vidro suspensas a alguma distância, por meio de uma tira de papel que se bifurcava, indo cada uma das bifurcações para uma das placas. Numa delas colocou um certo número de larvas do mesmo ninho, deixando a outra vazia. Uma formiga, devidamente marcada, foi posta na placa que continha as larvas. Tomando, em suas mandíbulas, uma das larvas, a formiga rumou com ela para o ninho. Voltou dentro em pouco com algumas companheiras. Assim que ela, que vinha à frente, chegou à placa das larvas, e antes que as outras houvessem atingido o ponto de bifurcação da ponte de papel, o experimentador inverteu a situação, de sorte que o ramo da pista que acabara de ser percorrido pela formiga marcada ia agora ter à placa vazia. Pois foi exatamente êste o rumo que tomaram as outras formigas. $O$ que elas seguiram foi evidentemente o cheiro deixado no caminho pela companheira que as precedeu.

Seria interessante conhecer a distância alcançada pelo faro poderoso dos Insetos.

Os Lepidópteros poderão fornecer-nos valiosas informações

Comecemos por citar uma observação de RILEY (1895). Aquêle autor criou, em Chicago, em cuidadoso confinamento, algumas mariposas da lagarta do Ailanthus, que não ocorriam a uma distância de muitos quilômetros do local. Uma fêmea virgem foi colocada numa caixa de vime sôbre um pé daquela planta e um macho marcado foi sôlto a cêrca de 3 quilômetros dali. No dia seguinte, o macho foi encontrado sôbre a caixa que encerrava a fêmea.

Também FABRE (1879-1904), havendo recebido um casulo da mariposa do carvalho, da qual havia mais de 20 anos näo vira na localidade um único exemplar, constatou que 65 machos vieram ao encontro da fêmea que dêle saíra, poucas horas depois daquela haver alcançado a maturidade sexual.

Ensaiando com as mariposas, verificou o célebre entomólogo francês, que recipientes contendo substâncias odoriferas co- 
locados nas imediações, não dificultavam o encontro das fêmeas, e que os machos procuravam pousar em todos os objetos em que aquelas tivessem tocado. De outro lado, pôde constatar, que os machos não conseguiam descobrir as fêmeas aprisionadas em caixas perfeitamente estanques para o ar, fazendo-o, porém, com facilidade, se nas paredes das caixas houvesse qualquer orifício, por menor que fôsse.

De posse dêsses conhecimentos acêrca do sentido do olfato nos Insetos, fácil se torna compreender como possa a vespa descobrir na região em que vive, o tipo de caça que lhe convenha.

Os receptores olfativos, super-sensibilizados nas condiçōes fisiológicas em que a fêmea se encontra quando premida pela necessidade de desovar, facilitam-lhe, ainda mais, a localização de sua vítima. A bem dizer, é a vítima que primeiro descobre a sua algoz. O cheiro particular que ela exala, de ação quimiotrópica fortemente positiva, vai atingí-la, onde quer que se encontre, e conduzí-la, de maneira inexorável, para a fonte que o produz. Basta que um impulso fisiológico coloque a vespa no marco inicial da estrada que deve percorrer. O resto virá naturalmente. O lutar, o subjugar a sua prêsa, o arrastá-la e tudo o mais, são impulsos inatos, que só se satisfazem, quando novos impulsos correm a cortina sôbre o ato em curso, para que o ato seguinte possa vir à cena. Com o último ato, que vem a ser, no caso, o fechamento da entrada do ninho, cai o pano de bôca e o espetáculo se termina pela cabal satisfação dos desígnios que compeliram a vespa a viver os acontecimentos garantidores da perpetuação da sua espécie.

Talvez essa história de cortinas que correm, de atos que se sucedem e de panos que caem, não tenha ficado bem clara.

O que de fato acontece quando a vespa é levada à reprodução pelas transformações que se processam no seu organismo; é o seguinte :

Sentindo a necessidade premente de descarregar os ovos que cresceram nas suas entranhas, prepara um ninho. Terminado êste trabalho, parte para a caça. Atraida por um cheiro que antes parecia não sentir, vai ao encontro da vítima. Ao vêla, um impulso irresistível, que só se sacia ao ferí-la com seu dardo venenífero, atira-a para a arena. A inoculação do veneno no corpo da vítima, ao mesmo tempo que apazigua os seus ardores belicosos, nela desperta a imperiosa necessidade de arrastá-la para o ninho. A visão dêste, determina o recolhimento da vítima. Uma vítima paralisada no interior do ninho, é o estímulo para a postura. A conclusão da postura compele-a a deixar o ninho e êsse ato determina a oclusão do orifício de entrada, com o que as ocorrências chegam ao seu têrmo. 
Como vimos, numa conduta complexa como a das vespas caçadoras, a satisfação de cada impulso torna o organismo responsivo para os estímulos que determinam o impulso imediato. Mais do que isso. A descarga normal de um impulso condiciona o impulso seguinte, de sorte que, se por qualquer circunstância o organismo não puder responder adequadamente a um dos estímulos, a série de atos se interrompe na etapa respectiva, e a conduta, não podendo completar-se, perde a significação que tem para a vida da espécie. Daí, o estabelecimento de uma sequência lógica, sem a qual a conduta não alcançaria o seu fim. Digo lógica, porque resultou da eliminação, pela seleção natural, no decurso do desenvolvimento filogenético da espécie, de tudo aquilo que viesse impedir ou dificultar que a conduta se cumprisse segundo os cânones que regem a evolução dos seres organizados. Assim como um órgão qualquer só se constitui normalmente se os organizadores e indutores que operam no embrião entrarem em atividade numa sequência lógica, para provocarem a gastrulação, a neurulação, a determinação e a diferenciação dos tecidos, assim também uma conduta só se completa de modo normal, se os estímulos se sucederem na verdadeira ordem. Da mesma maneira que o cristalino do ôlho do Anfíbio não se constitui sem que um divertículo da parte anterior do tubo neural alcance a face interna da ectoderme do embrião para aí induzir a formação da lente, também o impulso de arrastar a vítima para o ninho não se manifesta sem que antes a vespa tenha nela cravado o seu dardo paralisante.

Se as coisas fôrem realmente assim, não poderemos deixar de reconhecer o automatismo na execução dos atos que constituem uma conduta complexa. Automatismo, no sentido de que sem o estímulo apropriado 0 ato não se exerce e em face do estímulo não pode deixar de cumprir-se. $O$ estímulo desencadeia um impulso que obriga o animal a agir. A ação é, pois, uma resposta direta, específica e inevitável ao estímulo que a provoca, e nesse sentido é automática.

Busquemos os exemplos que corroboram essa maneira de ver. Em HINGSTON (1929), vamos encontrá-los.

Sphex lobatus, uma vespa caçadora de grilos, da fndia, procede nas seguintes etapas: escava a toca de um grilo; obriga-o a vir para fora; persegue-o até paralisá-lo; arrasta-o para a mesma toca de onde fôra expulso; recolhe-o; póe nêle um ôvo; fecha o buraco.

Havendo encontrado uma daquelas vespas no momento em que ela buscava descobrir o esconderijo de um grilo, atirou HINGSTON, ao solo, diante dela, um exemplar justamen- 
te da espécie procurada. Pela atitude da vespa, agitando as antenas, movendo-se para um e para outro lado, fazendo pequenos avanços, percebeu que ela havia reconhecido aquilo que procurava. Era só atacá-lo, paralisá-lo e arrastá-lo. Mas não. A vespa deixou-o escapulir-se. A experiência, várias vezes repetida, deu sempre os mesmos resultados. $E$ isso porque o que a vespa verdadeiramente buscava não era um grilo e sim a toca de um grilo. No bom desempenho de uma conduta secular, tinha ela que começar pelo comêço e seguir à risca as diferentes etapas na sequência fixada no patrimônio biológico da espécie. Atacar um grilo que ela não desentocou, não expulsou, não perseguiu, seria começar pela terceira etapa, o que ela não consegue fazer.

Mais um exemplo, ainda de HINGSTON.

Psammophila tydei, uma caçadora de lagartas, do Himalaia, descobre a sua vítima, crava-lhe o aguilhão oito vezes sucessivas, esmaga-lhe a cabeça mastigando-a com as mandíbulas, arrasta-a para o ninho, recolhe-a, põe nela um ôvo, vem para fora e fecha o buraco de entrada.

Pois bem. Uma dessas vespas caçava. HINGSTON oferece-lhe uma lagarta que acabara de ser recolhida ao ninho por outra vespa da mesma espécie. Trata-se, pois, de uma lagarta já paralisada e com a cabeça esmagada. Nada mais restavalhe a fazer, senão arrastá-la para o ninho e prosseguir como de costume, uma vez que a Providência quisera poupar-lhe as fadigas da busca e as incertezas do combate. Entretanto, não foi isso que fez a vespa. Ao avistar. a lagarta, inerte e indefesa, cai sôbre ela, pica-a como de orcuinário, mastiga-lhe a cabeça já esmagada e continua, no rítimo habitual, até concluir o úl timo ato da série.

A semelhança de Sphex lobatus, também Psammophila tydei não conseguiu concluir uma tarefa, uma vez que esta não foi por ela iniciada. $E$ isso, pela falta de impulsos adequados. O impulso de arrastar não se instala, sem que o impulso de paralisar e o de esmagar tenham-se descarregado. A vista da prêsa, por seu turno, é o estímulo irresistível que a compele a picá-la. E' porisso que ela pica, e, segundo a rotina, esmaga a cabeça de sua vítima, mesmo que esta já se encontre paralisada e com a cabeça esmagada.

HINGSTON teve também a oportunidade de interferir na conduta de certos besouros coprófagos (Gymnopleurus), que preparam, rolam e enterram uma bola de excremento, chegando a idênticos resultados.

Encontrando o excremento, os besouros, aos pares, constroem com êle uma bola, e, sempre juntos, rolam-na para um lugar 
conveniente e com ela se enterram, para comê-la. As etapas dessa complexa conduta, são: descobrir o excremento, construir a bola, rolá-la e enterrá-la.

A um par que se encontrava na segunda etapa da série, isto é, que trabalhava na confecção da bola, foi oferecida uma bola já feita.

Uma bola de excremento, modelada tal qual, seria sem dúvida uma dádiva do céu, que lhes pouparia tempo e esfôrço. Rolá-la dali, antes que outros pudessem dela se apoderar, seria o que de melhor deveriam fazer. Mas, qual! Na etapa de construir uma bola, uma bola tem que ser construida. $O$ impulso de rolar só se manifesta após um esfôrço próprio e não alheio. Não se diga que por serem muito exigentes êles só se satisfazem com a bola que êles mesmos construirem. Não, a bola que lhes foi oferecida, preenchia todos os requisitos. Apenas, os besouros não se encontravam ainda em condiçōes de rolá-la. Rolar, vem depois de fabricar. E tanto assim, que se o par se encontrar na terceira etapa da série, rolando uma bola por êles próprios preparada, aceitam, sem relutância, uma bola estranha. Roubando-lhes a bola que iam levando e dando-lhes em substituição uma que outros construiram, verificou o experimentador, que êles a aceitam incontinente e se pôem a rolá-la para o ninho.

Rolar, é a única coisa que podem fazer na etapa respectiva da série. Se lhes subtrairem a bola e não lhes oferecerem uma outra, serão incapazes de recomeçar. Mesmo que colocados sôbre o estrume, abandonam-no à procura da bola perdida. Rolar, e nada mais. Deem-nos uma bola, mesmo que não seja a nossa, e saberemos rodá-la. Os dois primeiros atos da conduta foram já representados e não poderemos bisá-los...

Há, evidentemente, uma completa cegueira na conduta dêsses animais. Não fôra a intervenção do investigador quebrando o ritmo de uma série de comportamentos que nas condiçōes naturais se repetem. sempre na mesma sequência, e a gente seria levada a admitir não somente deliberação de atitudes, mas também conhecimento acêrca da significação de cada uma das atividades que constituem a conduta complexa. Mas, a experiência veio mostrar que não há deliberação e muito menos conhecimento da finalidade dos atos que praticam. Os animais agem impulsionados pelos estímulos que se sucedem e na mais completa ignorância do significado de suas ações. Uma vez que a vista de uma lagarta viva ou morta estimula uma vespa da mesma maneira, ela se comporta do mesmo modo, cravandolhe nas carnes o aguilhão. $O$ impulso desencadeado não reco- 
nhece diferenças entre o vivo e o morto. Tem que se consumar e consuma-se. E', pois, inflexível.

De que os Insetos em questão não têm qualquer conhecimento acêrca da finalidade dos atos que executam, possuimos inúmeras e concludentes provas.

O caso da larva do Heterospilus, deixando viva na câmara uma segunda broca, depois de ter matado a primeira, ou, "matando mais uma vez" a broca morta que substituiu a outra, mostra, de maneira bem clara, que ela desconhece a finalidade do ato de matar. Nas mesmas condições se encontra a caçadora de grilos, que rejeita uma prêsa fácil, só porque não foi por ela própria descoberta e desentocada, e bem assim, a caçadora de lagartas, que crava, repetidas vezes, o dardo, no corpo inerte de uma vítima já paralisada, e esmaga-lhe, a seguir, a cabeça já esmagada! E os besouros que não sabem se aproveitar de uma bola de excrementos feita por indivíduos da mesma espécie!

Citemos mais alguns exemplos que servem para demonstrar a inflexibilidade da conduta.

FABRE, depois que a abelha Chalicodoma dera por terminada a construção dos seus potinhos de barro e se puzera a carregá-los com mel, ia retirando, com algodão, aquilo que ela ia depositando. Quando a abelha deu por concluido o provisionamento das células e iniciou o trabalho de fechamento, pôde FABRE verificar, que algumas achavam-se vazias, outras continham quase nada e outras, uma pequena carga.

Praticando um orifício no fundo das células, por onde o produto se escoava, chegou a idênticos resultados. Após ter recolhido a quantidade costumeira de provisão, a abelha obturava a entrada das células, sem haver notado que tôda a carga se havia esvaido pelo buraco do fundo.

A abelha carrega o ninho até satisfazer o impulso de "carregar". Em seguida, um novo impulso compele-a ao fechamento da bôca das células, contenham estas ou não, o produto do seu labor.

HINGSTON, experimentando com a vespa Eumenes, que constrói um certo número de células de argila, fez interessantes constatações.

Concluida cada célula, a vespa põe nela um ôvo e depois um certo número de lagartas, findo o que, fecha-a.

HINGSTON foi retirando uma por uma das lagartas introduzidas. Após haver roubado à vespa 9 de suas prêsas, foi obrigado a afastar-se e durante a sua ausência, a vespa trouxe mais duas, com as quais encheu a célula e deu por terminada a sua tarefa. 
Ao todo, 11 lagartas foram introduzidas, número evidentemente muito superior ao habitual e que daria para encher três células. Daí concluiu o experimentador, que a conduta de Eumenes não é tão rígida e tão cega quanto a de Chalicodoma, pois que, buscando uma quantidade excessiva de lagartas, parece ter revelado um lampejo de compreensão, uma vez que o impulso de provisionamento se satisfaz, de ordinário, com apenas duas ou três lagartas.

Podemos discordar da conclusão de HINGSTON.

A conduta de Eumenes, em nada de fundamental difere da conduta de Chalicodoma. O impulso de provisionamento é, pela sua natureza, elástico. Tanto uma como outra, darão um número variável de viagens, até completar a carga do ninho. A célula vazia ou incompletamente provisionada estimula uma nova saida à cata de material. Até quando o estímulo poderá manter acesa a chama do impulso, obrigando o animal a repetir o mesmo ato, depende da espécie e até mesmo da individualidade. Porém, é de se esperar que a fadiga mais cedo ou mais tarde intervenha no sentido de pôr um têrmo numa situação que não deve continuar indefinidamente. Então o animal abandona o seu trabalho no ponto em que se achar ou comete o êrro de concluí-lo, passando para a etapa seguinte, como se a anterior tivesse sido realizada de maneira normal.

Não houve, da parte de Eumenes, o menor indício de entendimento. Apenas ela repetiu, com relação a uma das células, um ato, muito mais vezes do que costuma fazer. Mas o estímulo permanecia e a sua conduta manteve as características de uma conduta normal. Concluida a célula, na vespa se instalou o impulso de enchê-la. Esse impulso não tem limites definidos. Se a primeira lagarta fôr suficientemente grande para tomar tôda a célula, êle se satisfaz com uma só descarga. Se, pelo contrário, após a introdução da primeira vítima, fica ainda muito espaço vazio, o impulso se repete e novas lagartas são trazidas e isso, até que se satisfaça a capacidade da célula. Foi o que aconteceu, na experiência de HINGSTON, só depois de haver a vespa recolhido 11 lagartas, 9 das quais foram subtraidas. As duas últimas, tendo enchido a célula, satisfizeram, cabalmente, o impulso de provisionamento.

A única conclusão que me parece legítimo tirar-se da experiência que acabámos de relatar, é que o mesmo impulso pode repetir-se muito mais vezes que de ordinário, contanto que o estímulo ali esteja para reavivá-lo.

Uma vez que o impulso deu-se por satisfeito pelo enchimento da célula com as duas últimas lagartas, não se ficou sabendo o que aconteceria caso o experimentador permanecesse a pos- 
tos, esvasiando a célula. A vespa, nessas condições, talvez cometesse o mesmo êrro de Chalicodoma ou perturbada, abandonasse o trabalho.

Sabe-se, realmente, que um ato, uma vez cumprido, pöe o organismo em situação de praticar o ato seguinte. Mas, se ao envés de ser estimulado à prática do novo ato, o animal continua recebendo o mesmo estímulo que condicionava 0 ato anterior, êle fica como que amarrado à mesma etapa da série, repetindo-a um grande número de vezes.

Foi o que observou FABRE, com Sphex flavipennis.

Essa vespa caçadora de grilos, antes de recolher a sua prêsa ao ninho, nêle penetra para uma ligeira inspeção. Se tudo encontrar em ordem, recolhe a sua vitima.

Enquanto uma Sphex estava examinando o ninho, afastou FABRE para uma certa distância o grilo que ela acabara de largar à bôca do buraco. Ao sair para recolhế-lo, evidentemente não o encontrou no lugar em que o avia deposto. Depois de uma pequena busca, deu com êle, e se pôs a arrastá-lo, como de costume. Porém, se havia de recolhê-lo diretamente, uma vez que a visita ao ninho já tinha sido feita, larga-o novamente e penetra para a inspeção. O experimentador, disso se aproveitando, de novo afasta o grilo. Encontrando-o pela segunda vez, a vespa o arrasta até a entrada do ninho, deixa-0, e ingressa para a vistoria.

Quarenta vezes repetiu FABRE a mesma operação e 40 vezes comportou-se a vespa da mesmissima maneira.

Paralisado o grilo, vem o impulso de arrastá-lo. A vista do ninho obriga a vespa a depor a sua carga e nêle penetrar. Ao sair, o encontro do grilo à porta, faz com que ela o recolha. No desempenho normal e automático de uma conduta inata, não se recorda o animal das etapas já vencidas, muito embora seja êle dotado da faculdade da memória. Porisso, ao deparar com o grilo a uma certa distância, ignora, a vespa, na verdade, em que etapa da série se encontra. A vista do grilo paralisado estimula-a à prática de dois atos distintos: arrastá-lo, o que se verifica loga após a paralisação (2a. etapa), ou recolhê-lo, o que se dá ao terminar a inspeção do ninho (4a. etapa).

Ao agarrar o grilo nas condições da experiência, tem, pois, a vespa, apenas duas coisas a fazer: arrastá-lo ou recolhê-lo. Recolhê-lo, não é possivel, pois se encontra longe do ninho. Tem por conseguinte, que arrastá-lo. Para uma vespa que arrasta a sua prêsa, a vista do ninho é o estímulo que determina a inspeção e ela outra cousa não faz senão ceder áquele imperativo. De mais a mais, arrastar e recolher são dois atos muito semelhan- 
tes para que entre êles se estabeleça uma barreira intransponível.

Em se tratando de atos muito distintos, como por exemplo construir uma bola de excrementos e depois rolá-la para o ninho, compreende-se que o Inseto, da etapa de "rolar", não consiga voltar à etapa de "construir", tal como se verificou na experiência de FABRE com o besouro Gymnopleurus. Também, da fase de provisionamento não pode a vespa voltar à fase de construção de um potinho de barro, embora, enquanto constrói, possa reparar um orifício praticado em sua parede.

Mas, arrastar e recolher um grilo, ao contrário de fabricar e rolar uma bola de estrume ou construir e carregar um potinho de barro, são atividades da mesma natureza, que bem podem ser executadas sem interrupção. Porisso, não seria de estranhar, que nas condições anormais criadas pela experiência, uma vespa acabasse por recolher o seu grilo, saltando a etapa da inspeção. Aliás, foi o que se deu, quando o próprio FABRE e também o casal PECKHAM e FERTOIN, repetiram, com outras espécies de Sphex e com Pompilus, a experiência de efastar a prêsa enquanto a vespa inspeciona o ninho. De fato, verificaram que depois de se comportarem duas, três ou quatro vezes, como a primeira Sphex de FABRE, penetraram no ninho sem mais depositar a carga à porta para uma nova visita.

O encontro de uma tal solução para uma situação anormal que chega a ser aflitiva, pode ser o resultado do distúrbio que a quebra do ritmo introduz na conduta das vespas. A fôrça de repetir alternadamente os mesmos atos vai-lhes gradativamente despertando a memória, de sorte que ao arrastar a sua vítima pela terçeira ou quarta vez, a vespa se sente como se já houvesse executado essa etapa da série e ao avistar o ninho, sente-se como se tivesse acabado de deixá-lo, e dessa confusão surge a solução do problema.

O grau de rigidez dos diferentes segmentos da conduta seriada, varia, naturalmente, com as espécies. Em muitos casos o impulso satisfaz-se com uma única descarga e o animal, na impossibilidade de repetí-lo, vê-se na contingência de abandonar a sua atividade. Foi, por exemplo, o que constatou o casal PECKHAN (1905), com uma Pompilus caçadora de aranhas, que acabara de paralisar a sua vítima. Como essa vespa costuma colocar a prêsa sôbre uma planta enquanto se dirige ao ninho para inspecioná-lo, aproveitaram-se os PECKHAM da sua ausência, para substituir a aranha paralisada por uma aranha incólume da mesma espécie. Dando, ao regressar, com um animal ativo, abandonou-o, a vespa, sem conseguir picá-lo, vis- 
to como o impulso de "picar" fôra já satisfeito. Aliás, tínhamos visto que a larva do Heterospilus, depois de satisfazer numa broca o impulso de matar, constroi o casulo e entra em ninfose em presença de uma segunda broca.

O impulso de matar (Heterospilus) ou de paralisar (Pompilus), quando se descarrega num só objeto, é, pela sua nature$\mathrm{za}$, mais rígido. Jamais o Heterospilus, nas condições naturalmente fixadas no decurso de sua evolução, teria necessidade de matar mais de uma vez. Porisso, consumado o ato a que o arrasta o impulso, o animal se sente impossibilitado de responder de novo ao mesmo estímulo, sobretudo porque a conclusão do ato age sôbre êle de maneira muito forte, compelindo-o a executar $O$ ato seguinte da série. $E$ assim, deixa a larva da vespinha de matar uma segunda broca experimentalmente introduzida na câmara e se pôe a tecer o casulo para a ninfose.

O mesmo se dá com certas caçadoras de aranhas que se contentam com um único exemplar. Paralisado êste, recusam. se elas a atacar um segundo, comportando-se como a Pompilus da experiência dos PECKHAM.

Enquadra-se aqui uma interessante observação de HINGSTON, com Psammophila tydei.

Caça essa vespa e enterra uma só lagarta. Havendo colocado um ôvo no corpo de sua vítima, estava ela trabalhando no entupimento do ninho, usando, como de costume, pedrinhas e caquinhos. Havia já obstruido metade da galeria, quando HINGSTON, aproveitando-se de uma de suas ausências, desenterrou a lagarta e colocou-a à entrada. De regresso, embora tendo visto a sua prêsa inanimada do lado de fora e até pisado nela, foi incapaz de recolhê-la, prosseguindo, como se nada de anormal tivesse acontecido, na tarefa de entupimento, até a sua conclusão. Sem demonstrar qualquer interêsse pela lagarta que ali jazia a seus pés, esparramou a terra sôbre a bôca obstruida do ninho, procurando disfarçá-la da melhor maneira, e partiu, como de costume.

Mas, se a vespa tem por hábito caçar um número variável de indivíduos, os impulsos que condicionam os diferentes atos, repetindo-se alternativamente nas condiçōes normais, não se devem mostrar inflexíveis às repetições experimentais. Foi assim que FERTON, colocando uma lagarta paralisada à entrada do ninho que acabara de ser suprido e fechado por uma Ammophila, constatou, à semelhança de FABRE com a Sphex caçadora de grilos, que a vespa, ao deparar à saida com mais aquela lagarta, pôs-se a abrí-lo, movida, naturalmente, pelo impulso de recolhê-la. Desobstruindo a entrada, encontra a vespa a célula repleta. Uma célula repleta é exatamente o estímulo que 
desencadeia o impulso de fechar. Entulha de novo com areia a entrada do ninho. Ao concluir, vê a lagarta do lado de fora e recomeça a abrí-lo. Dando com êle repleto, fecha-o outra vez...

Nem mesmo quando o animal procura esconder o seu ninho, quer recobrindo-o cuidadosamente com o material que se encontra nas imediações, quer executando uma verdadeira obra de arte capaz de dar a um potinho de barro a mesma aparência da casca da árvore sôbre a qual foi construido, nem assim se pode pensar numa ação deliberada, de finalidade conhecida. A conduta, também aqui, mostra-se cega, o animal nada mais fazendo que cumprir um determinismo fisiológico cuja significação para a vida da espécie êle desconhece da maneira a mais cabal.

Habitam certas aranhas carangueijeiras um túnel escavado na terra e munido de uma porta provida de dobradiça, que se adapta perfeitamente ao orifício de entrada, mas que facilmente se pode abrir para lhes dar passagem. As que constróem sua vivenda em terra coberta de musgo, não deixam de cobrir a parte externa da porta com aquêle material, de sorte que a entrada desaparece no meio esverdeado que o circunda. Retirando-se a porta e raspando-se o chão para expor a terra, as aranhas constróem uma porta nova, revestem-na de musgo e dessa maneira tornam muito conspícua a entrada do túnel, que se destaca, como um círculo verde, da terra nua, que a rodeia. (HINGSTON, 1929).

O Reverendo C. P. CORY, assistiu, segundo HINGSTON (o. c.), a obra completa de uma vespa, Sceliphron intrudens, que construira o ninho na chaminé do seu gabinete de estudo. Quando aquêle parecia concluido, pôs-se a vespa a ornamentálo, gastando nessa tarefa cêrca de 15 dias. Com paciência e arte, conseguiu imitar com perfeição a casca de uma árvore, não se esquecendo dos líquens que se costumam encontrar sôbre os ramos.

Tal disfarce, preparado com requintes de detalhes, durante duas semanas, servem bem para demonstrar a ignorância da vespa artista, acêrca da significação da sua obra. Sôbre uma árvore, o ninho estaria perfeitamente camuflado; mas, sôbre uma chaminé, punha-se em grande destaque. $O$ jardineiro, talvez não conseguisse descobrí-lo lá fora, mas a arrumadeira daria logo com êle.

No mimetismo encontramos, senão a explicação, pelo menos um valioso auxílio, para um melhor entendimento dêsse aspecto particular da conduta.

Um ninho, evidentemente não é uma conduta, mas sim o resultado objetivo da conduta. A conduta vale simplesmente 
como uma função orgânica : a função de produzir um ninho. E, nesse sentido, em nada de especial ela difere das demais funções. Assim como a função digestiva, com todos os seus complexos, produz no organismo os aminoácidos, os monossacaridios, os ácidos graxos, indispensáveis à vida do indivíduo, assim também a função nidificadora produz, para o organismo, o ninho, indispensável à vida da espécie. Os produtos da digestão e o ninho, são apenas os resultados das respectivas funções. $O$ animal quando digere ou nidifica, não tem ciência do que está fazendo. Tanto num caso como no outro, apenas responde a estímulos adequados, quer derramando sôbre os alimentos os sucos digestivos, quer descarregando sôbre o material apropriado os impulsos nidificadores.

Certos animais imitam objetos do meio em que vivem, confundindo-se com êsses objetos e dêsse modo, ocultando-se. E' uma das formas do mimetismo. $A$ imitação às vezes é feita com excessos de detalhes. Citemos o exemplo dos Fásmidas, cujo corpo reproduz a forma exata de um raminho sêco, recoberto de líquens e com manchas como as produzidas pelos fungos do carvão, da fumagina ou da ferrugem. Tal é o caso de Otocrania pleuracantha. E os Pseudophyllidae que se parecem com fôlhas verdes, sêcas ou com o ápice sêco e a base ainda verde? $\mathbf{E}$ os Lepidópteros do gênero Zaretes, cujas fêmeas pela fece ventral, são verdadeiras fôlhas sêcas, com os bordos quebrados e o parênquima, em parte corroido e cheio de pústulas ?

Ora, um ninho de vespa, que, pelo aspecto exterior se confunde com o ramo da planta em que se acha, é um caso de mimetismo. Só que aqui se trata de um mimetismo tardio, comparativamente ao mimetismo somático. A natureza do fenômeno é, porém, a mesma. Tanto faz tratar-se de asas como de ninhos, o processo de desenvolvimento responsável pela exteriorização do caráter se acha do mesmmo modo inscrito no patrimônio hereditário da espécie. Asas de Lepidópteros, que se parecem com fôlhas, e ninhos de Himenóptercs que imitam a casca dos ramos, pertencem, umas e outros, à ontogênese do respectivo organismo.

As formigas nos dão também exemplos do automatismo da conduta.

Messor barbarus armazena no formigueiro sementes de gramíneas. As sementes recolhidas são beneficiadas e a palha é trazida para fora e depositada num monte a cêrca de 8 polegadas do orifício de entrada, distância considerada suficiente para manter sempre livre a porta do ninho.

Os indivíduos incumbidos do transporte da palha não se desfazem da sua carga sem primeiro percorrer aquela distân- 
cia. Nas condições normais, tudo vai muito bem. Certa vez, porém, HINGSTON observou a atividade das formigas que haviam escavado a sua habitação numa parede vertical. Umas entravam com as sementes e outras saiam com a palha. Estas, depois de caminhar as 8 polegadas costumeiras, arreavam cuidadosamente o seu fardo, como se quisessem iniciar com êle a formação de um monte. Numa parede vertical, mal as operárias largavam a palha, e esta caia para o chão. Por meses trabalharam as formigas sem que alterassem os seus métodos no sentido de se aproveitarem de um fenômeno tantas vezes repetido, qual o da queda da palha. Era só largar a carga logo à saida do buraco, e a gravidade se incumbiria do resto. Mas não, sem dar aquêles passos que deram todos os seus ancestrais para amontoar a palha a 8 polegadas da entrada da habitação, não seria possível trabalhar! Ou se trabalha segundo as normas seculares seguidas pelos antepassados, ou nada se faz.

Com o intúito de mostrar que a conduta revela-se igualmente rígida também nos Vertebrados, cita BIERENS DE HAAN (1946), o caso dos pombos referido por LORENZ.

Os pombos se revesam no ninho durante o chôco, deitandose a fêmea desde a tarde até a manhã do dia seguinte, e o macho, da manhã dêsse dia até a tarde do mesmo dia. Assim que a fêmea vem rendê-lo, o macho se afasta e à tardinha regressa para ficar tôda a noite ao lado de sua companheira.

Havendo a fêmea sido eliminada por um gato, aconteceu que o macho, ao voltar das suas horas de folga, encontrou o ninho vazio. Mas, como a tarefa da noite não lhe cabia, acomodouse de um lado, deixando que os filhotes morressem em consequência do intenso frio que fazia. Pela manhã, à hora da rendição, aninhou-se, como de costume, aquecendo com o calor do seu corpo o cadáver irregelado dos filhinhos.

A rigidez da conduta, ou melhor, a fôrça do estímulo, torna de fato cego o animal. E nessa iplacável cegueira vai êle ao ponto de não conseguir distinguir o vivo do morto. Que isso aconteça com vespas, que aguilhoam uma prêsa já morta só porque precisam descarregar o impulso de paralisar, ainda vá. Mas que as Aves e até mesmo os Mamíferos se comportem diante de corpos empalhados, da mesma maneira que se comportavam antes, atinge as raias do incrivel. Entretanto, narra MISS PITT (1931), sem esconder a sua emoção, a história da pavoa Rachel e de seus dois filhotes, Joan e Darby.

Havendo morrido Rachel, MISS PITT, inspirada na narrativa de SIR ARTHUR THOMSON, de uma vaca que perdera a cria e em consequência tornara-se irrequieta e prendera o leite, mas que, em presença do corpo empalhado do seu bezerro, não 
só o lambia carinhosamente, como se deixava ordenhar, resolveu retirar a pele da pavoa e armá-la, enchendo-a de palha, para estudar a conduta dos filhotes. Embora, como ela mesma confessa, o trabalho executado deixasse muito a desejar, os pavõezinhos continuaram a tratar a mãe, como se estivesse viva. Subiam-lhe ao dorso, deitavam-se ao lado, corriam para ela quando assustados, dormiam debaixo daquele corpo mal ageitado, tudo fazendo na mais normal das atitudes, alegres e calmos, e isso, mesmo depois que a pele entrara em decomposição e o mau cheiro atraira uma coorte de moscas.

Aliás, essa incapacidade de distinguir o objeto vivo - estimulador natural da conduta - de imitações inanimadas e às vezes grosseiras, tem sido tratada por vários experimentadores.

HASTLEY (1950) verificou que certas aves que reagem de modo característico à presença de corujas, procedem de idêntica maneira não só diante das peles, como também de meras silhuetas de cartão, contanto que estas guardem determinadas proporções e reproduzam alguns caracteres somáticos das corujas. PETERS (1948), igualmente, constatou que os peixinhos que buscam proteger-se na cavidade bucal da mãe, correm para uma silhueta de cartão, assim que se sentem assustados ou atemorizados.

\section{SÔBRE A RIGIDEZ E A PLASTICIDADE DA CONDUTA}

Uma questão assás importante, sôbre a qual tem havido muita discussão, é a que se refere à apreciação da regidez da conduta. Afirmam alguns, que a conduta é absolutamente rígida, ao passo que outros a consideram mais ou menos plástica e até mesmo capaz de variaçōes adaptativas.

Tudo depende, antes de mais nada, de definições. E' preciso saber primeiro o que se deve entender por rigidez e por plasticidade, para depois se discutir se a conduta deve ser considerada rígida ou plástica.

Comecemos por afirmar que o rígido e o plástico existem lado a lado na natureza e que sendo a plasticidade uma das características fundamentais do mundo organizado, nem porisso deixa a rigidez de nêle intervir para fixar os limites, sem os quais, não se poderiam reconhecer as características que separam os seres vivos entre si, ou do mundo inanimado que os rodeia.

Um cristal de sal de cozinha é plástico no sentido de poder ser pulverizado, fundido, dissolvido; mas é rígido no sentido de se manter como sal de cozinha e não poder dar pelo desdobramento de suas moléculas, senão os iontes $\mathrm{Na}$ e $\mathrm{Cl}$. 
Uma ameba é extremamente plástica no sentido de mudar continuamente de forma, de responder de maneira diferente a estímulos por seu turno diferentes, emitindo lobopódios ou filipódios, conforme o caso, ou se imobilizando numa forma arredondada; é, porém, rígida, no sentido de ser sempre a mesma ameba. O ôlho humano é plástico no sentido de poder ser azul, verde ou pardo, grande, oblíquo, saliente, redondo, assemelhando-se, muitas vezes, ao ôlho do boi, do carneiro, da coruja, do gato ou do peixe. Todavia, é rígido, no sentido de ser sempre o ôlho humano. $O$ cavalo doméstico, tão plástico com relação à pelagem, ao tamanho, ao vigor, à velocidade, à conformação, ao temperamento, mostra-se rígido no sentido de jamais ter deixado de ser o cavalo doméstico de todos os tempos. Um disco ocular da larva crescida da Drosophila é rigido no sentido de não poder formar nenhum outro órgão que não seja o ôlho; é, entretanto, plástico, no sentido de poder dar um ôlho branco, vermelhão, eosina, sinabar, etc., o que depende dos fatôres genéticos operantes no organismo. A respiração do Mamífero é plasstica no sentido de poder alterar o seu ritmo e de processar-se numa atmosfera mais rica ou mais pobre em oxigênio, gás carbônico, azôto, mais úmida ou mais sêca, mais pura ou mais impura; é, não obtante, rígida, no sentido de não poder efetuar uma troca de gáses com um meio líquido.

A ectoderme do embrião novo de Anfíbio é plástica. Uma área mais ou menos limitada, que, pela sua posição, deveria se constituir em pele, tomará parte na formação do sistema nervoso central, se for incluida nos tecidos que deverão constituir os órgãos daquele sistema. Assim também, tecidos que deveriam produzir órgãos nervosos, poderão se converter em pele.

Mais tarde, aquelas mesmas áreas tornam-se rígidas: o que deveria produzir pele, produzirá pele e o que deveria formar órgãos nervosos, formará órgãos nervosos, onde quer que se desenvolva.

Quaisquer partes da ectoderme que receber a indução da cápsula ocular darão origem a um cristalino. Porém, sòmente enquanto forem plásticas. Mais tarde, tornar-se-ão rígidas e só produzirão aquilo que verdadeiramente lhes cabia no desenvolvimento normal, mesmo quando submetidas à ação de agentes indutores de outras estruturas.

As espécies são plásticas, nelas não se encontrando sequer dois individuos que se possam considerar como perfeitamente iguais. Mas são rígidas no que se refere à sua constância como unidade biológica. O Homo sapiens, por exemplo. Em 
que pese a sua notável plasticidade, tem sido sempre o mesmo Homo sapiens das cavernas pré-históricas. Rígido, portanto.

Nessa ordem de idéias, teremos que a conduta é rígida e ao mesmo tempo plástica. E' rígida como um atributo específico sempre presente e plástica na maneira de exteriorizar-se. Como qualquer outro caráter da espécie, é rigida por fôrça de um imperativo hereditário e plástica pelo jôgo dos fatôres que determinam as variações indivíduais. Rígida por hereditariedade, plástica por flutuação.

O que é importante na apreciação da conduta é a sua rigidez como caráter específico. Sendo hereditária, ela deve aparecer como um patrimônio da espécie, comum, portanto, a todos os seus membros. A plasticidade verificada na maneira particular de proceder cada indivíduo ao descarregar os seus impulsos inatos, não altera a natureza da conduta.

A questão do grau de plasticidade constitui, sem dúvida, um problema de difícil apreciação. Os exemplos geralmente citados representam as mais das vezes meras observações e as experiências não passam de simples inter:venções destituidas de qualquer rigor científico. Começa, que nem a determinação específica dos animais estudados é rigorosa, nem a biologia suficientemente conhecida. Da constituição genética do material, nem se fale. Só pelo fato de um investigador ter feito uma intervenção esporádica na conduta de uma vespa e constatado ser ela incapaz de repetir um ato já executado, não se pode concluir seja isso realmente a regra. Talvez um ato, pela sua natureza, não possa mesmo ser repetido, enquanto outros poderão sê-lo. Os resultados contraditórios, por sua vez, poderão ser atribuidos a diferenças genéticas não tomadas em consideração.

O impulso obriga a vespa a picar e nêsse particular é rígido. Agora, a maneira dela dar cumprimento àquela imposição constitucional, depende das circunstâncias. A luta pode ser mais viva ou mais moderada e o ataque iniciar-se pela frente ou por trás, por um ou por outro flanco. Ass vezes uma picada, às vezes duas ou mais. Depende da reação defensiva oposta pela vítima, do seu volume e vigor, bem como do poder entorpecente da peçonha inoculada e da sua quantidade. $E$ tudo isso varia de um indivíduo para outro. E' por essa razão que no ninho da mesma vespa podem-se encontrar algumas prêsas em estado de completa imobilidade, outras semi-paralisadas, outras em perfeita atividade.

Segundo FERTON, a mesma espécie de Pompilus, que na Córsega paralisa a sua aranha com duas aguilhoadas, na Algéria põe o ôvo sôbre a sua vítima, sem tentar picá-la. Mas, como as aranhas caçadas nessas duas regiões filiam-se a famílias mui- 
to diferentes, é bem provável que o Pompilus corso e o algeriano, se não forem especificamente distintos, pertençam pelo menos a duas raças geográficas diferentes. Aliás, conhecem-se espécies que se não deixam distinguir pela morfologia, mas que se não confundem por caracteres de outra ordem. Estão nesse caso algumas espécies de Drosophila, que apenas se diferenciam por caracteres fisiológicos ou ecológicos.

$O$ objeto que age como estimulador da conduta, pode variar, sem que, muitas vezes, possamos descobrir a sua variação.

O fato de uma espécie de lagarta só se alimentar de uma espécie de planta, não significa que ela não possa se servir de outras plantas para o mesmo fim. Talvez a ocasião não tenha ainda chegado dela ensaiar outra dieta, parecendo porisso especificamente amarrada a uma única sorte de alimento.

Sendo a nutrição um fenômeno de vital importância, é de se esperar que o animal tenha possibilidades adaptativas em potencialidade, que lhe permitam alargar o campo de suas explorações. A especialização, embora exista, não é, em geral, muito estreita. A regra, é um polifagismo mais ou menos dilatado.

A broca do café, que se saiba, só ataca os frutos do cafeeiro. Mas, mesmo assim, o seu campo de atividade não é absolutamente restrito, pois infesta, indiferentemente, diversas espécies daquela Rubiácea. Animais carnívoros podem comer só mamíferos, só aves ou só peixes. Embora tenham suas preferências, servem-se, contudo, de um grande número de espécies. O mesmo se dá com os insetívoros.

Os carrapatos são, em geral, polífagos. A mesma espécie pode sugar algumas dezenas de hóspedes distintos, incluindose animais domésticos e selvagens. Algumas são mais especializadas, atacando um número bem mais limitado de espécies. Porém, nunca poderemos prever a amplitude da plasticidade, porque não dispomos de elementos para julgar do que seria ainda capaz um carrapato. Uma espécie que na Europa suga o boi, o carneiro e a cabra, nada revela acêrca de suas aptidões potenciais em relação ao tatú, ao tamanduá ou à cotia. Mas no Brasil, o mesmo carrapato estende a sua ação também sôbre êstes animais.

O que se acha no ser, como capacidade latente, não pode ser conhecido e nem sequer suspeitado, antes que se revele, ficando na dependência de condições às vezes imprevisíveis.

Se a conduta, dentro dos rígidos limites que a caracterizam, goza, como vimos, de uma certa plasticidade, não é para se estranhar, que objetos diferentes possam levar o animal à prática do mesmo ato, conduzindo-o, dêsse modo, a uma sorte de experiência, que pode ou não, ter significação para a vida da es- 
pécie. Ainda mais, que objetos diferentes para a apreciação humana, são, muitas vezes, semelhantes, para o animal.

Animais que não distinguem as côres, encontram semelhanças naquilo em que o homem só vê divergências. $A$ baixa acuidade olfativa do homem, por outro lado, impede-o de distinguir odores que para o olfato animal são inconfundiveis. Pode, porisso, acontecer, que o objeto sôbre o qual se descarrega um impulso, que para o observador humano se mostra grandemente variável, o seja, na realidade, em grau muito pequeno ou nulo, para o animal.

Suponhamos uma vespa, que, guiada pelo olfato, caça indiferentemente duas ou três espécies distintas de aranhas. Os centros olfativos da vespa, não conseguindo distinguir os odores das aranhas, estimulam-na da mesma maneira. $O$ objeto que regula a conduta é, pois, nesse caso, simples (um determinado cheiro), e não múltiplo, como possa parecer (diversas aranhas diferentes).

Alguns autores, referindo-se à variabilidade adaptativa da conduta, citam a observação de FERTON com uma espécie de abelha do gênero Osmia, que reveste o seu ninho com pétalas vermelhas de papoula. Acontece, porém, que na Corsega, a abelha utiliza pétalas amarelas de Glaucium e nos Pirineus, pétalas azuis de Malva.

Nada se conhece acêrca das possibilidades visuais de Osmia relativamente à coloração das flores. Sabe-se, contudo, de uma longa experimentação, que a abelha doméstica é cega para o vermelho e confunde um grande número de côres que o homem distingue com facilidade, mas, em compensação, vêm côres que pertencem à zona ultra-violeta do espectro e que escapam à percepção humana. Para os olhos de Osmia as flores da popoula, do Glaucium e da Malva, podem parecer azul-verdes, estimulando-os da mesma maneira.

Se o Inseto não consegue distinguir duas ou mais côres êle poderá receber o mesmo estímulo visual de flores que para nós diferem grandemente. Mas, é muito provável, que não só os foto-receptores, mas também os receptores olfativos, tenham o seu papel a desempenhar. $\mathbf{E}$ assim, o Inseto, levado a visitar flores de coloração diferente, submeta-as a um teste olfativo. Se nada na flor o repelir, êle se servirá dela, como o fazia antes com uma outra. Executa, por assim dizer, uma sorte de revisão olfativa, do objeto indicado pela visão. Aliás, segundo von FRISH (1948), as abelhas, atraidas pelo colorido das flores, guiam-se depois pelo olfato.

A vista e o olfato são sentidos que operam à distância; o gôsto e o tacto, em contacto com o objeto. E', pois, natural, que 
êstes dois últimos sentidos exerçam uma função controladora da conduta. E dêsse modo, uma conduta aparentemente simples, decompõe-se, na realidade, em atos as mais das vezes pouco distintos, dependendo cada qual de um estímulo sensorial diferente.

O animal é conduzido a um objeto pela vista ou pelo olfato. Se a vista age primeiro, o olfato decidirá depois. Se, pelo contrário, o animal é orientado pelo cheiro de um objeto que êle não vê, a vista só mais tarde poderá intervir.

Mesmo depois que a vista e o olfato tenham entrado com a sua contribuição, o gôsto e o tacto poderão interferir para modificar a conduta. A forma, a côr e o cheiro de um fruto podem determinar no animal os impulsos de comê-lo. O gôsto, porém, seria capaz de transformar os impulsos de aceitação, em impulsos de rejeição. Entretanto, se êsse sentido não intervier para impedir o aproveitamento daquele fruto, o animal o comerá, sejam quais forem as consequências. Poderá ter descoberto um alimento novo, mas poderá igualmente sucumbir, caso se trate de um fruto venenoso. Não houve, evidentemente, aqui, um êrro dos sentidos, pois o fruto exibia tôdas as condições para estimular de uma maneira normal a conduta de comer. $\mathrm{O}$ animal foi simplesmente vitimado pelas suas deficiências orgânicas de vez que não dispunha de mais um sentido que lhe desse informações acêrca da toxidez das substâncias. Se escapar a ação dos venenos do fruto desconhecido, a prova valerá por uma experiência, que, à fôrça de ser repetida, acabará anulando os mesmos impulsos que antes o compeliam para aquêle objeto nocivo. Entretanto, a conduta assim modificada, em nada valerá à espécie, jamais deixando a esfera individual.

Os impulsos de nutrição e de reprodução responsáveis, respectivamente, pela conservação do indivíduo e pela perpetuação da espécie, podem ser mais especializados ou mais ecléticos, segundo os casos.

Se o animal se desenvolve sem qualquer contacto com os indivíduos que lhe deram origem, precisa vir ao mundo armado de potencialidades inatas que respondam de modo específico e no momento oportuno aos estímulos que farão com que êle se nutra, fuja aos inimigos da espécie ou se defenda, nidifique ou se reproduza, tal como fizeram todos os seus antepassados. Ele deve possuir aquela mesma e integral sabedoria hereditária responsável pelos triunfos dos seus semelhantes nas lutas pela existência.

E assim, uma vespa que nasce no interior de um buraco cavado na terra, deve possuir todo um repositório de potencialidades, que, despertadas por estímulos adequados, farão com 
que ela descubra a mesma aranha que vem servindo, através das gerações, para o sustento dos jovens da sua espécie; que, sem jamais ter assistido as peripécias da caça ao aracnídio, saiba com êle lutar e ferí-lo, segundo a mesma técnica que vem sendo empregada desde tempos imemoriais; que o arraste para um ninho que em nada de fundamental difira do ninho antes construido pelos seus ancestrais; que saiba desovar na sua vítima e fechar a entrada do ninho, tal como sempre fizeram aquêles que the deram origem.

Mas, se o animal, ao nascer, conta com a assistência dos pais, em cujo convívio permanece por um tempo mais ou menos longo, os impulsos são menos especializados e a melhor conduta fica dependendo de aprendizagem. A avesita, ao contrário da vespa, não precisa descobrir o alimento que mais lhe convenha, porque disso se incumbirão os seus pais. Os filhotinhos implumes dos pássaros escancaram a enorme bôca os pais lhes derrubam na guela faminta o alimento que buscaram para êles. E nem os primeiros sabem que alguém lhes provê a subsistência, nem os segundos, que estão provendo a subsistência de alguém. Estímulos imprecisos como os produzidos por qualquer vibração do ninho, arrancam aos passarinhos o impulso de abertura do bico. De outro lado, qualquer cousa que se assemelhe à bôca receptora dos filhotes, como por exemplo, meros cartuchos de papel, estimula os pais a largarem o alimento que trazem no bico.

As aves que nascem implumadas e se mostram ativas desde que largam a casca do ôvo, aprendem com a mãe, que os protege e defende, a escolher os seus alimentos. A única cousa de inato que possuem é o impulso de bicar. Bicam tudo, inclusive pedrinhas e até mesmo as sombras projetadas no chão e que imitam pequenos objetos. A mãe, entretanto, se encarrega de indicar-lhes quais as coisas que verdadeiramente devem ser bicadas.

Também nos mamíferos não existem propriamente impulsos de mamar, mas apenas de sugar. O recém-nascido suga tudo que é quente e mole. O leitãozinho, por exemplo, antes de descobrir que as têtas da porca são o único objeto que apazigua os impulsos de sugar, suga-lhe a cauda, as orelhas, os pêlos.

Deve-se isso principalmente ao fato das condutas complexas e de vital importância para a comunidade, serem, neste caso, inespecíficas.

Nada há de mais relevante para a vida da espécie, do que as relações que se estabelecem entre mãe e filhos, quando êstes, ao nascer, necessitam de proteção e de alimentos, que não 
sabem providenciar sozinhos. Vemos então os escorpiōezinhos amontoados no dorso da mãe, cuja cauda, voltada para a frente, sôbre êles se movimenta, sempre pronta para fazer entrar em ação o aguilhão mortífero em que se termina. Nos primeiros dias de vida são os filhotes incapazes de caçar, pois a sua frágil arma de ataque não se liga ainda à glândula venenífera da extremidade da cauda. Vemo-los então descer do dorso materno para se banquetear com o suco que escorre do corpo da vítima que sua mãe caçou e dilacera para êles. Vemos os peixinhos nadando em volta da mãe, a alguma distância, precipitarem-se para ela e ser por ela recolhidos na bôca, único meio de escaparem à sanha devoradora de outros peixes. Vemos os pintinhos ao redor da galinha, que vai ciscando e bicando numa verdadeira demonstração de como se deve proceder para encontrar alimentos; vemo-los, quando assustados, buscar abrigo sôb as protetoras asas maternas. Vemos o bezerro e o poldro, sempre juntos à mãe, que os amamenta e defende.

$\mathrm{E}$ tudo isso, que numa linguagem antropoística poderia ser chamado de "amor materno" e "amor filial", é a manifestação de uma conduta complexa, e, ao contrário do que poderia parecer, inespecífica. Não existe aqui "uma certa e determinada" mãe, protegendo e nutrindo "certos e determinados" filhos. Não, o que existe são duas unidades biológicas não específicas, "mãe" e "filho", indispensáveis para que os impulsos maternais e filiais, estimulando-se mutuamente, possam se traduzir num complexo típico de atividades recíprocas. Do ponto de vista "estímulo-reação", a mãe não é dêste ou daquele filho, e nem o filho pertence a esta ou aquela mãe. Mas o elemento "mãe" do complexo "mãe - filho", simplesmente reage com o elemento "filho" do mesmo complexo. Não fôra assim, e a permuta de elementos com outro complexo da mesma natureza, seria impossível. E no entanto sabemos, que tanto nos escorpiões, como nos peixes, nas aves ou nos mamíferos, podemos substituir os recém-nascidos por recém-nascidos de outra mãe, sem qualquer alteração perceptível nos impulsos que motivam a reciprocidade da conduta. Interessante é notar, que mesmo a mulher, que representa o grau supremo da evolução psíquica, nem ela seria capaz de decidir entre dois recém-nascidos, aceitando como seu aquêle que lhe for apresentado e com êle reagindo de maneira perfeitamente normal.

Ora, diante de tudo isso, não é de admirar que uma vespa que só caça uma determinada espécie de grilo, lá uma ou outra vez, capture um gafanhoto.

O mesmo se dá relativamente ao material empregado na confecção do ninho e bem assim ao local escolhido para a nidi- 
ficação. $\mathrm{E}$ nesse particular, como em muitos outros, ninguém poderá fazer conjecturas acêrca das possibilidades latentes do animal.

Quem poderia supor que as corujas fôssem capazes de nidificar nos campanários, antes que os campanários existissem? Que as vespas pudessem construir o seu ninho nas paredes de uma casa ou as andorinhas nos beirais, antes que o homem tivesse abandonado as cavernas dos primeiros dias da sua história? Que o João de Barro armasse o seu forno num poste de ferro, antes que o telégrafo riscasse com seus fios a amplidão das terras?

Não, o que precisa manter-se é aquilo que a conduta tem de fundamental : nidificar à maneira dos antepassados, segundo um plano básico de ação. Isso é o essencial. A natureza do barro não tem importância nem para a vespa, nem para o pássaro forneiro. Nem um nem outro examina o barro para saber se as partículas de argila são mais finas ou mais grossas, qual a proporção de areia ou se nêle existe ferro ou calcário. Pode o barro ser o escuro das terras roxas ou o claro das areníticas. Não obstante tôdas as variações conhecidas, a conduta deixase reconhecer, na consecussão de um plano pré-estabelecido, como a conduta patrimonial da espécie.

O desenvolvimento da humanidade e os crescentes progressos da indústria humana, enriquecendo o meio de objetos manufaturados, oferecem ao animal uma fonte inexgotável de novos estímulos. Não há, da parte do animal, nenhuma reação defensiva visando anular o efeito estimulador daqueles objetos, exatamente por se tratar de elementos artificiais, que de maneira alguma poderiam ter influido na evolução dos seus impulsos naturais. E' porisso que o Coleóptero Cerambicídio $\mathrm{Me}$ gaderus stigma é levado a desovar nos tubos de chumbo que protegem os condutores telefônicos ou elétricos, sacrificando as suas larvas, que em vão perfuram o metal, com sérios prejuizos às respectivas Emprêsas, na tentativa inútil de nutrir-se. (CORLOS MOREIRA, 1930; D. BENTO PICKEL, 1929). E' porisso, igualmente, que o pássaro João Tiriri (Synallaxis sp.) introduziu, na confecção do seu ninho, pedaços de arame de diversos tamanhos, inclusive arames farpados, desafiando a argúcia interpretativa dos ornitólogos. (P. F. SCHIRCH, 1931).

Estes desvios esporádicos da conduta, nocivos uns, neutros ou até mesmo úteis outros, servem para demonstrar o acêrvo imprevisível de potencialidades latentes de que dispõe o animal. 
Outras vezes, os desvios da conduta, não obstante aparentemente estravagantes, desenvolveram-se no decurso da evolução e se incorporaram ao patrimônio hereditário da espécie, sendo porisso considerados como perfeitamente normais. Seria, por exemplo, o caso dos Himenópteros que tentam copular com o labelo das flores de certas espécies de Orquídeas. Estas plantas, como se sabe, necessitam dos Insetos para a fertilização. Não dispondo de um nectar capaz de atraí-los, muitas espécies são providas de um labelo cuja conformação permite-lhes explorar o ardor genésico de certos Himenópteros. E' assim que os machos, estimulados pela forma do labelo, tentam com êle copular, tendo sempre a cabeça voltada para o lado daquelas pequenas pétalas que imitam as antenas das fêmeas, tal como fazem nas condições normais. Contribui para a estimulação dos machos à prática do ato sexual, o fato dêles nascerem muitos dias antes das fêmeas, estando, porisso, sob a pressão dos componentes fisiológicos de uma conduta, para a qual se acham há muito preparados. (BAERENDS, 1950).

\section{CONSIDERAÇÕES ACERCA DA CONDUTA INSTINTIVA E DO INSTINTO}

A conduta instintiva, como vimos, caracteriza-se por ser inata. Aparece no animal por efeito das leis da hereditariedade e se transmite como qualquer outro caráter, fixando-se como um atributo da espécie. Sendo assim, a conduta não se modifica a não ser pelas chamadas "mutações" e só varia dentro dos limites permitidos pelas flutuações devidas às influências do meio.

$\mathrm{Na}$ conduta instintiva, por conseguinte, temos que reconhecer dois componentes: um, que é o componente fundamental e que representa, por assim dizer, um plano básico de ação; e outro, um componente modal, que se refere à maneira pela qual se põe em execução aquêle plano básico.

Construir um "ninho de João de Barro" e não de "Beijaflor" ou de "Guacho", seria o componente fundamental da conduta nidificadora instintiva do pássaro forneiro. Servir-se, para tanto, de um barro claro ou escuro, erguer o forno numa árvore ou num poste, com a entrada olhando para êste ou aquêle quadrante, formariam o componente modal daquela conduta.

O componente fundamental é rígido, sendo herdado tal qual por todos os membros da espécie; o componente modal é plástico, variando com as circunstâncias e de indivíduo para indivíduo. 
A aprendizagem, portanto, só afeta a parte modal da conduta. Não interessando à parte fundamental, não consegue deixar o âmbito individual e dêsse modo não pode ser inscrita no patrimônio da espécie, tôda a habilidade adquirida pelo indiví. duo, com êle desaparecendo.

A conduta instintiva, de conformidade com a sua maior ou menor complexidade, manifesta-se por uma série de atos que se desenrolam numa sequência definida, de tal sorte, que um ato qualquer só se processa, depois de concluido o ato anterior. Durante a execução de um ato o organismo torna-se indiferente aos estímulos que desencadearam os atos anteriores e não se mostra ainda receptivo com relação aos estimulos dos atos seguintes. A conclusão de um ato, portanto, prepara o organismo para o ato imediato, tornando-o sensitivo para os estímulos adequados.

Nenhuma conduta instintiva se processa sem que o organismo esteja fisiologicamente preparado para isso. Assim, nos Mamíferos, antes que as gônadas e as outras glândulas endócrinas relacionadas com a reprodução atinjam o estado de maturidade funcional, a conduta sexual não se manifesta, mostrando-se o macho indiferente aos objetos que estimulam aquela conduta, não tomando, por exemplo, conhecimento, da presença de uma fêmea em estado de cio. Do mesmo modo, é necessário que o organismo da fêmea sofra as modificações introduzidas pela gestação e pelo parto, para que ela possa representar os atos que caracterizam a conduta maternal.

Uma outra característica da conduta instintiva, é que ela sempre tem um significado adaptativo que conduz a um fim de grande importância para a vida do indivíduo ou de espécie. Entretanto, o animal não possui conhecimento algum daquele fim, nem tão pouco dos meios a empregar para atingí-lo. Age compelido por estímulos, internos uns, externos outros, que o levam à execução automática dos atos que caracterizam a conduta. Esta aparece como a consequência útil de uma concatenização lógica de procedimentos inatos, estabelecida pelas leis que regem a evolução das espécies. Cada ato em si, de uma conduta complexa, embora hereditário e por conseguinte inato, só tem significação para a conduta em curso, quando executado na ordem estabelecida pelo processo evolutivo criador da conduta. Isoladamente, $o$ ato perde aquêle sentido remoto que tem quando intercalado no seu devido lugar, só conservando o sentido atual.

Para que uma conduta seja considerada instintiva, não é necessário que os atos executados pelo animal, o sejam igualmente. Estes podem muitas vezes ser, e o são realmente, meros 
reflexos ou tropismos. O essencial é que o ato seja intercalado na devida ordem, na série que conduz ao fim visado.

Encontra-se com frequência na literatura psicológica "instinto" e "conduta instintiva" empregados indiferentemente. Há, entretanto, entre os dois conceitos, fundamental diferença, que pretendo estabelecer com base, principalmente, em preceitos de ordem genética.

Começarei afirmando que "instinto" é a faculdade que dá ao animal a possibilidade de executar a conduta. Esta é, pois, objetiva, ao passo que o instinto não passa de mera virtualidade. Como virtualidade, $o$ instinto só existe em potencialidade, só podendo ser conhecido através da conduta. Não obstante, o instinto existe independentemente da conduta, podendo a qualquer momento ser posto em evidência. Por exemplo, um rato novo, muito longe ainda da maturidade sexual, e, porisso mesmo, indiferente aos estímulos provenientes de uma fêmea em estado receptivo, já possui o instinto de copular à maneira dos seus antepassados. $O$ que lhe falta são os hormônios que lhe preparam o organismo, tornando-o responsivo aos estímulos respectivos. Algumas injeções daquelas substâncias ativas bastarão para fazer com que $o$ instinto em potencial se revele numa conduta perfeitamente característica da espécie, levando o ratinho a executar, na mesma sequência e da mesma forma, todos os atos da conduta sexual, e isso, mesmo que êle tenha sido criado em completo isolamento, sem jamais ter presenciado a prática daqueles atos. Além disso, o instinto continua existindo e se transmitindo de pais a filhos, ainda quando impedido de se exteriorizar. De fato, se os descendentes de uma vespa criada em laboratório e que aí não pôde nidificar à maneira dos seus, o fazem na natureza, é porque o instinto nidificador, apesar de inibido pelas circunstâncias artificiais que cercaram a sua progenitora, nela existia em estado potencial e foi-lhes integralmente legado.

A conduta instintiva, pelo contrário, não pode existir independentemente do instinto. Aliás, sendo ela a exteriorização do instinto, necessita dêste para se manifestar. Assim, um Beijaflor, jamais construirá um ninho de João de Barro, porque o instinto de nidificar à maneira do João de Barro é privativo daquela espécie. Assim também, um rato branco nấo tem medo de cobra (KELLOGG, 1931), porque não possui aquêle "instinto de medo", que RICHARDSON (1942) pôs em evidência no rato selvagem, Neotonia abigula.

Geneticamente falando-se, o instinto representa um caráter genotípico e como tal se acha figurado no ôvo de que o animal se origina. A conduta instintiva, por seu turno, corresponde ao fenótipo, ou seja, áquilo que aparece no decurso do de- 
senvolvimento em consequência da atividade dos fatôres hereditários presentes no genótipo. Tal como acontece com qualquer outro caráter fenotípico do indivíduo, a conduta instintiva pode variar dentro dos limites permitidos, sem alterar o genótipo. $\mathrm{E}$ como a aprendizagem ou a educação só interessam ao fenótipo, qualquer alteração da conduta devida a circunstâncias exteriores, deixa de aproveitar à espécie por não poder se inscrever no genótipo do indivíduo.

As mutações, pelo contrário, alterando a constituição genética, podem ser o ponto de partida para uma modificação hereditaria da conduta, a qual, por essa razão, se incorpora ao patrimônio do grupo.

Infelizmente, o genótipo, não podendo ser atingido pelos agentes do meio, não há processo educacional algum que possa modificá-lo no sentido de introduzir uma alteração benéfica na conduta instintiva.

\section{LITERATURA}

BAERENDS, G. P. 1950 - Specialization in organs and movements with a releasing function. Symp. Soc. Exp. Biol. 4.

BIERENS DE HAAN, J. A. 1946 - Animal Psychology, London et al.

BUYTENDIJK, F. J. J. 1936 - The mind of the dog, London.

FABRE, J. H. 1879-1904 - Souvenirs entomologiques, Paris.

FRISH, C. v. 1948 - Aus dem Leben der Bienen, Wien.

HARTLEY, P. H. T. $1950-$ An experimental analysis of interspecific recognition. Symp. Soc. Exp. Biol. 4.

HINGSTON, R. W. G. 1929 - Instinct and intelligence, New York.

KELLOG, W. N. 1931 - A note on fear behavior in young rats, mices end birds. Jour. Comp. Psych. 12.

LUBBOCK, J. 1883 - Ants, bees and wasps, New York.

MOREIRA, C. 1930 - Insectos que corroem o chumbo. Inst. Biol. Def. Agric. Minist. Agric. Bol. N. 8. 
PECKHAM, G. and E. G. Peckham, 1905 - Wasps social and solitary, Westminster.

PERTY, M. 1830 - Delectus animalium etc.

PETERS, H. M. 1948 - Grungfragen der Tierpsychologie, Stutgart.

PICKEL, D. Bento, 1929 - Sôbre um coleoptero perfurador de cabos telephonicos observado em Pernambuco. Bol. Mus. Nac. 5 (4).

PITT, F. 1931 - The intelligence of animals, London.

PIZA, S. de Toledo, 1953 - Aspectos íntimos do Japão, Limeira.

PIZA, S. de Toledo e J. P. da Fonseca, 1955 - Heterospilus coffeicola Schmied parasita da "broca do café" Stephanoderes hampei (Ferr.) Arch. Inst. Biol. 6.

RICHARDSON, W. B. 1942 - Reaction toward snakes as shown by the wood rat, Neotonia abigula, Jour. Comp. Psych. 34 .

RILEY, C. V. 1895 - The senses of insects, Nature, 52.

ROMANES, G. J. 1887 - Experiments on the sense of smell in dogs, Nture, 36.

SCHIRCH, P. F. 1931 - Sôbre um ninho construido de arame de um passaro brasileiro. Bol. Mus. Nac. 7 (2). 